\title{
Preemption After Wyeth v. Levine
}

\author{
DOUGLAS G. SMITH*
}

TABLE OF CONTENTS

I. THE BACKGROUND OF THE WYETH DECISION

A. The History of Federal Regulation of

Pharmaceutical Products...

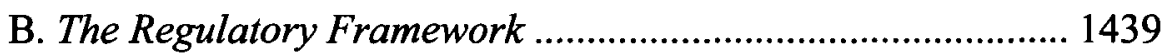

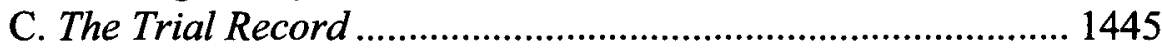

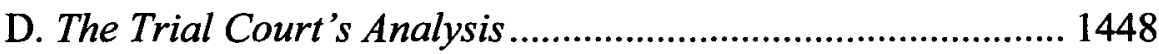

E. The Vermont Supreme Court's Analysis............................... 1450

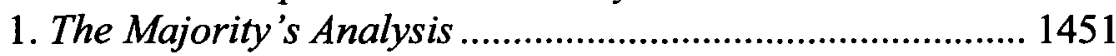

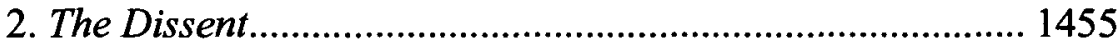

II. THE SUPREME COURT'S DECISION ......................................... 1458

A. The Majority Opinion...................................................... 1458

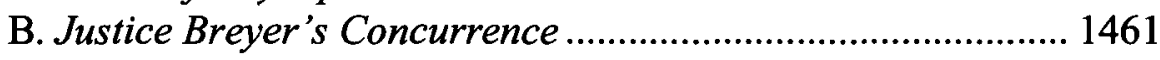

C. Justice Thomas's Concurrence ........................................... 1462

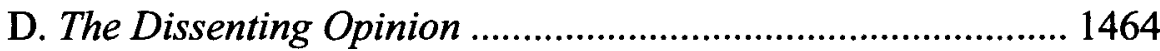

III. The Scope of Preemption After Wyeth...................................... 1466

A. A Context-Dependent Analysis............................................... 1467

B. Preemption After Notice-and-Comment Rulemaking.............. 1470

C. Preemption Where There Is an Approved Use....................... 1471

D. Preemption of Fraud-on-the-FDA Claims ............................. 1471

IV. WYETH IN THE CONTEXT OF THE COURT'S OTHER PREEMPTION CASES

V. The Balance THe CourT Has StRUCK ................................. 1474

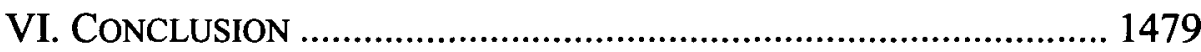

In recent years, the Supreme Court has actively defined the scope of federal preemption. In a series of decisions, it has interpreted the various preemption doctrines broadly to prohibit state action that interferes with important federal policies. In Riegel v. Medtronic, Inc., for example, it

* Partner, Kirkland \& Ellis LLP; Distinguished Scholar in Residence, Loyola University Chicago School of Law. J.D., Northwestern University School of Law; M.B.A., The University of Chicago; B.S./B.A., State University of New York at Buffalo. The opinions expressed in this article are personal to the author and do not necessarily reflect those of Kirkland \& Ellis LLP or its clients. 
reaffirmed the strong federal preemption of state tort lawsuits involving medical devices. ${ }^{1}$ Likewise, in Buckman Co. v. Plaintiffs' Legal Committee, the Court ruled that so-called "fraud on the FDA" claims were preempted by the federal regulatory regime. ${ }^{2}$

Thus, the Court's recent decision in Wyeth $v$. Levine ${ }^{3}$ was surprising. In Wyeth, the Court held that the Food and Drug Act did not preempt a state-law tort suit for failure to warn of the alleged dangers of a pharmaceutical product. ${ }^{4}$ Specifically, the Court found that the Act did not preempt a statelaw tort suit alleging that the labeling for an anti-nausea medication, Phenergan, did not sufficiently warn about the risks associated with IV-push administration of the drug. ${ }^{5}$ It therefore affirmed the ruling of the Vermont Supreme Court that upheld a jury verdict against the manufacturer brought by a musician whose arm had been amputated after she developed gangrene as a result of improper administration.

Already, Wyeth has been interpreted by some as sounding the death knell for the preemption doctrine in the context of pharmaceutical products. ${ }^{6}$ However, a careful analysis of the Court's decision indicates that this is far from the case. The majority underscored that its decision was a "narrow" one based largely on the facts and circumstances before it. ${ }^{7}$ In particular, the Court made a point of noting that the record was devoid of evidence that the particular risks at issue had actually been considered by the FDA and that the defendant had thus failed to show that there was an actual conflict between

1 128 S. Ct. 999, 1001 (2008).

2531 U.S. 341, 344 (2001); see also Daniel E. Troy \& Rebecca K. Wood, Federal Preemption at the Supreme Court, 2007-2008 CATO SUP. CT. REV. 257, 258 (observing that "the Court does appear to be deciding in favor of preemption somewhat more often than usual, and by greater margins").

3 129 S. Ct. 1187 (2009).

${ }^{4}$ Id. at 1204.

${ }^{5}$ Id.

${ }^{6}$ See, e.g., Erwin Chemerinsky, Wyeth is Victory for Consumers, Blow to Preemption, 45 TRIAL 54, 56 (2009) ("Wyeth is a significant decision and a major victory for consumers, and if the Court follows its own commands, preemption faces a much more difficult future.'); Margaret Cronin Fisk, Ruling Reopens Drug Lawsuits, NEWARK STAR-LEDGER, May 3, 2009, at D1 ("Every failure-to-warn case against a drug company has been affected' by the Wyeth ruling, said Michael Miller, a plaintiffs' attorney in Alexandria, Va."); Miriam Hill, High Court Upholds Right to Sue Drugmakers, PHILA. INQUIRER, May 5, 2009, at A1 ("The [Wyeth] case had been billed as the most important business decision in several years because it is likely to affect consumer litigation against many industries.").

${ }^{7}$ See Wyeth, 129 S. Ct. at 1194. 
FDA regulation and the state-law tort suit. ${ }^{8}$ The majority's analysis therefore suggests that state-law tort suits based on an alleged failure to warn are preempted in cases in which the FDA has specifically considered the particular risks at issue and has determined that the pharmaceutical product's labeling adequately warns of those risks.

Such a ruling would not only be consistent with the analysis in Wyeth, but would have significant benefits. As the Court has repeatedly recognized, there is an inherent tension between the congressional establishment of a federal regulatory regime for the labeling of pharmaceuticals and medical devices by experts at the FDA and allowing a jury of ordinary citizens with no specialized expertise to render their own judgment regarding, and in effect overrule, such expert determinations. The FDA typically engages in extensive review and analysis of drug labeling not only before it is initially promulgated, but on an ongoing basis to ensure that it is consistent with the safe and effective use of the pharmaceutical product. As several members of the Court have noted, there is a potential danger in allowing these expert decisions to be undermined by state court juries. ${ }^{9}$ Moreover, such an outcome may have undesirable indirect effects, such as raising the prices of pharmaceutical products to satisfy state-court judgments that are not warranted based on the best available scientific evidence and the potential confusion and inconsistency that may result with juries in fifty-two separate jurisdictions imposing different standards concerning what constitutes appropriate labeling.

All of these considerations may have been in the minds of the majority in rendering the Wyeth decision. While the majority ruled that preemption did not apply under the particular circumstances of that case, a fair reading of the Court's decision leaves the door open to the continued application of the preemption doctrine in other failure-to-warn cases. In particular, the Court's decision appears to contemplate the continued application of the preemption doctrine in cases in which the FDA has specifically considered the particular risks that are the subject of a state-law tort suit. Accordingly, the Court may soon be called upon to further articulate the standards for determining the circumstances under which FDA action preempts state-law tort claims.

\section{THE BACKGROUND OF THE WYETH DECISION}

A proper understanding of the Wyeth decision requires consideration of the unique factual circumstances under which the case arose as well as the

\footnotetext{
${ }^{8}$ See id. at 1199.

${ }^{9}$ See, e.g., id. at 1204 (Breyer, J., concurring); id. at 1230 (Alito, J., dissenting).
} 
regulatory framework in which the preemption decision was made. The federal government has had a long-standing role in the regulation of pharmaceutical products, spanning over a century. Nonetheless, the Food, Drug and Cosmetic Act (FDCA) does not expressly preempt state-law tort claims. Rather, the Court has found that there is an implied preemption where FDA regulation is implicated. In Wyeth, this doctrine ran up against a very sympathetic set of circumstances, in which the plaintiff suffered significant injuries based on the use of a method, the risks of which she claimed had not been fully considered, if considered at all, by the FDA in approving the drug decades earlier.

\section{A. The History of Federal Regulation of Pharmaceutical Products}

The federal government has had a long-standing role in the regulation of pharmaceutical products. In 1906, Congress passed the Pure Food and Drug Act, which sought to prevent the manufacture and interstate shipment of adulterated or misbranded pharmaceutical products. ${ }^{10}$ Three decades later, Congress passed another statute, the Food, Drug, and Cosmetic Act, which was broader in scope and required the approval of drugs by the federal government before they were placed on the market to ensure that they were safe if used according to their labeling. ${ }^{1}$ Congress amended the FDCA in 1962 , placing the burden of proof on the manufacturer to determine that a pharmaceutical product was safe for use according to the proposed labeling and that the drug was in fact effective if used according to the labeling. ${ }^{12}$ In passing such measures, Congress sought to "assure the safety, effectiveness, and reliability of drugs" before they were placed on the market. ${ }^{13}$ Most recently, Congress again amended the FDCA in 2007 to expand the FDA's authority. Among other things, it authorized the FDA to require manufacturers to change their labeling based on safety information that emerges after a pharmaceutical product's initial approval and to conduct additional post-approval studies. ${ }^{14}$

10 See Pure Food and Drug Act, Pub. L. No. 59-384, 34 Stat. 768, 768 (1906).

11 See Food, Drug and, Cosmetic Act, Pub. L. No. 75-717, ch. 675, 52 Stat. 1040, 1052 (1938).

12 See Drug Amendments of 1962, Pub. L. No. 87-781, §§ 102(d)9, 104(b), 76 Stat. $780,781,784$.

${ }^{13}$ Id. at 780 .

${ }^{14}$ Food and Drug Administration Amendments Act of 2007, Pub. L. No. 110-85, § 901(a), 121 Stat. 823, 924-26. 


\section{B. The Regulatory Framework}

In order for a pharmaceutical product to receive FDA approval, a manufacturer must submit a New Drug Application that contains information regarding the benefits and risks associated with the product. ${ }^{15}$ The NDA must contain "full reports of investigations which have been made to show whether or not such drug is safe for use and whether such drug is effective in use,"16 the labeling the manufacturer proposes for the pharmaceutical, "a discussion of why the benefits [of the pharmaceutical product] exceed the risks" under "the conditions stated in the labeling," 17 and "any other data or information relevant to an evaluation of the safety and effectiveness of the drug product obtained or otherwise received by the applicant from any source." 18 The FDA then undertakes a detailed review of the submitted material in order to determine whether the drug is "safe for use under the conditions prescribed, recommended, or suggested in the proposed labeling," whether there is "substantial evidence that the drug will have the effect it purports or is represented to have under the conditions of use prescribed, recommended, or suggested in the proposed labeling," and whether, "based on a fair evaluation of all material facts, such labeling is false or misleading in any particular."19

The FDA must deny any application that does not "include adequate tests by all methods reasonably applicable to show whether or not such drug is safe for use under the conditions prescribed, recommended, or suggested in the proposed labeling." 20 In addition, the application must contain "substantial evidence" to demonstrate a drug's efficacy, defined as follows:

"[S]ubstantial evidence" means evidence consisting of adequate and wellcontrolled investigations, including clinical investigations, by experts qualified by scientific training and experience to evaluate the effectiveness of the drug involved, on the basis of which it could fairly and responsibly be concluded by such experts that the drug will have the effect it purports or is represented to have. ${ }^{21}$

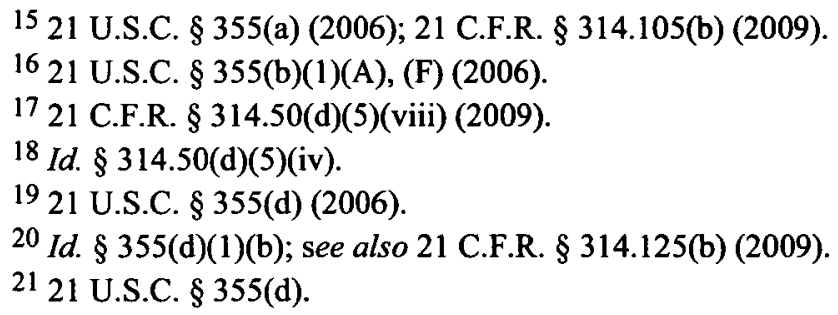


The FDA thus scrutinizes and approves the final labeling for all pharmaceutical products using a rigorous evaluation process to ensure that they are safe and effective if used according to the labeling. ${ }^{22}$

In doing so, it balances the benefits and risks associated with a pharmaceutical product and weighs the scientific data supporting the various claims and warnings. This balancing is inherent in the FDA's mandate because "virtually every drug or device poses dangers under certain conditions." ${ }^{23}$ Accordingly, the FDA "generally considers a drug safe when the expected therapeutic gain justifies the risk entailed by its use."24 The FDA likewise "is required to exercise its scientific judgment to determine the kind and quantity of data and information an applicant is required to provide for a particular drug to meet the statutory standards." 25 Moreover, where it deems it appropriate, it may require manufacturers to conduct post-marketing studies to collect additional information regarding "risks, benefits, and optimal use."26 Finally, the FDA crafts labeling in order to reach an appropriate balance between the risks and benefits of the particular pharmaceutical product. ${ }^{27}$ In doing so, it requires a warning where there is "reasonable evidence of an association of a serious hazard with the drug."28

22 In addition to review by its own team of experts, the FDA may also consult with independent scientific experts. See 21 U.S.C. $\$ 355(n)$ (2006). Such expert advisory panels must include individuals "qualified by training and experience to evaluate the safety and effectiveness of the drugs" under review and must, "to the extent feasible, possess skill and experience in the development, manufacturer, or utilization of such drugs." Id. $\S 355(\mathrm{n})(3)$. The FDA strives to select individuals with "diverse expertise in such fields as clinical and administrative medicine, pharmacy, pharmacology, pharmacoeconomics, biological and physical sciences, and other related professions." Id.

23 FDA v. Brown \& Williamson Tobacco Corp., 529 U.S. 120, 142 (2000); see also Riegel v. Medtronic, Inc., 128 S. Ct. 999, 1008 (2008) (observing that the FDA must often decide "[h]ow many more lives will be saved by a [pharmaceutical product] which, along with its greater effectiveness, brings a greater risk of harm"); United States v. Rutherford, 442 U.S. 544, 555 (1979) ("Few if any drugs are completely safe in the sense that they may be taken by all persons in all circumstances without risk.").

24 Rutherford, 442 U.S. at 555.

2521 C.F.R. § 314.105(c) (2009).

2621 C.F.R. § 312.85 (2009).

27 See 50 Fed. Reg. 7452, 7470 (Feb. 22, 1985) ("Drug labeling serves as the standard under which FDA determines whether a product is safe and effective."); see also 21 C.F.R. $\$ 201.56$ (a) (2009) ("[L]abeling must contain a summary of the essential scientific information needed for the safe and effective use of the drug[;] labeling must be informative and accurate and neither promotional in tone nor false or misleading in any particular[;] labeling must be based whenever possible on data derived from human experience.").

2821 C.F.R. $\S 201.80($ e) (2009). 
After the initial approval, the FDA continues to monitor the safety and effectiveness of approved drugs. ${ }^{29}$ Manufacturers have a continuing obligation to report adverse events experienced by individuals taking the drug. ${ }^{30}$ Adverse events that are "serious" and "unexpected" must be reported to the FDA "as soon as possible but in no case later than 15 calendar days of initial receipt of the information by the applicant." 31 The FDA also requires the submission of periodic postmarketing reports on a quarterly and annual basis discussing adverse events as well as all "significant new information ... that might affect the safety, effectiveness, or labeling of the drug." 32 The FDA "shall" withdraw approval of a drug if it finds that it is not safe when used in accordance with the labeling. ${ }^{33}$

In recognition that the scientific understanding of a drug's benefits and risks may change over time, the applicable statutes and regulations contemplate that the FDA may approve changes to the initial labeling. Accordingly, applicants may submit a Supplemental New Drug Application for consideration by the FDA in the event that they believe that changes in the labeling are warranted. ${ }^{34}$ FDA regulations also allow manufacturers to alter a product's label without prior approval by the agency under certain circumstances. The FDA's "changes being effected" (CBE) regulation states that changes may be made to the labeling without FDA approval to strengthen the warnings or instructions regarding dosage and administration:

(6) The agency may designate a category of changes for the purpose of providing that, in the case of a change in such category, the holder of an approved application may commence distribution of the drug product involved upon receipt by the agency of a supplement for the change. These changes include, but are not limited to:

(iii) Changes in the labeling ... to accomplish any of the following:

${ }^{29} \mathrm{See}$ FDA, Postmarketing Surveillance Programs (2009), http://www.fda.gov/Drugs/GuidanceComplianceRegulatorylnformation/Surveillance/ucm 090385.htm.

3021 C.F.R. $\S 314.80(c)(2009)$.

${ }^{31}$ Id. $\S 314.80(\mathrm{c})(1)(\mathrm{i})$.

${ }^{32}$ Id. $\S \S 314.80(\mathrm{c})(2), 314.81(\mathrm{~b})(2)(\mathrm{i})$.

3321 U.S.C. $\$ 355(\mathrm{e})(2006)$ (noting that FDA may withdraw approval if "on the basis of new information ... the labeling of such drug, based on a fair evaluation of all material facts, is false or misleading in any particular and was not corrected within a reasonable time after receipt of written notice from the [FDA] specifying the matter complained of').

${ }^{34}$ See 21 C.F.R. $§ 314.70(\mathrm{~b})(2)(\mathrm{v})(\mathrm{A})(2009)$; FDA, supra note 29. 
(A) To add or strengthen a contraindication, warning, precaution, or adverse reaction;

(C) To add or strengthen an instruction about dosage and administration that is intended to increase the safe use of the drug product ....35

The rationale behind this provision seems to be that manufacturers should not be forced to wait for FDA approval before providing additional information regarding the potential risks associated with a pharmaceutical product. However, such changes are ultimately subject to FDA review and approval. ${ }^{36}$

The FDA had issued a series of statements over time suggesting that its approval of drug labeling did not automatically have an across-the-board preemptive effect. In 1974, for example, the FDA acknowledged the existence of parallel state-law tort litigation in regulations designed to maintain the confidentially of adverse drug reaction reports. ${ }^{37}$ In 1979, for example, the FDA stated that "[i]t is not the intent of the FDA to influence the civil tort liability of the manufacturer." 38 In 1994, it stated that "product liability plays an important role in consumer protection." 39 And, in 1998, it stated that it did not intend "to preclude the states from imposing additional labeling requirements." 40

Likewise, there had been intermittent statements by Congress that opponents of preemption had cited to suggest that Congress did not intend that the FDCA have a preemptive effect. Thus, for example, in the amendments to the FDCA enacted in 1962, Congress included a clause stating that "[n]othing in the amendments made by this Act to the Federal

3521 C.F.R. $\S 314.70$ (c) (2009).

36 As one former FDA Chief Counsel has observed, such requirements mean that "[t]he actual freedom of manufacturers unilaterally to change the packet insert is minimal." Richard M. Cooper, Drug Labeling and Products Liability: The Role of the Food and Drug Administration, 41 FOOD DRUG COSM. L.J. 233, 236 (1986). Other FDA counsel have maintained that Congress "did not intend to preempt state tort remedies for injury to individual consumers." Margaret J. Porter, The Lohr Decision: FDA Perspective and Position, 52 FOOD \& DRUG L.J. 7, 9 (1997); see also id. at 11 (maintaining that "FDA product approval and state tort liability usually operate independently, each providing a significant, yet distinct, layer of consumer protection").

37 See Food and Drug Administration: Public Information, 39 Fed. Reg. 44601, 44602 (Dec. 24, 1974).

38 Labeling and Prescription Drug Advertising; Content and Format for Labeling for Human Prescription Drugs, 44 Fed. Reg. 37434, 37437 (June 26, 1979).

39 Protecting the Identities of Reporters of Adverse Events and Patients; Preemption of Disclosure Rules, 59 Fed. Reg. 3944, 3948 (Jan. 27, 1994).

40 Prescription Drug Product Labeling, 63 Fed. Reg. 66378, 66384 (Dec. 1, 1998). 
Food, Drug, and Cosmetic Act shall be construed as invalidating any provision of State law ... unless there is a direct and positive conflict between such amendments and such provision of State law."41

However, in 2006, while the Wyeth litigation was still pending, the FDA issued a new statement on preemption that arguably marked a shift in course for the agency. ${ }^{42}$ The FDA maintained that state failure-to-warn claims posed an obstacle to the agency's enforcement of the FDA's labeling requirements: "FDA believes that under existing preemption principles, FDA approval of labeling under the act, whether it be in the old or new format, preempts conflicting or contrary State law." 43 In addition, the FDA took the position

41 Drug Amendments of 1962, Pub. L. No. 87-781, § 202, 76 Stat. 780, 793 (1962).

42 Requirements on Content and Format of Labeling for Human Prescription Drug and Biological Products, 71 Fed. Reg. 3922 (Jan. 24, 2006) (to be codified at 21 C.F.R. pts. 201, $314 \&$ 601). For a critique of the FDA's regulation, see David A. Kessler \& David C. Vladek, A Critical Examination of the FDA's Efforts to Preempt Failure-toWarn Claims, 96 GeO. L.J. 461 (2008).

4371 Fed. Reg. at 3934. More specifically, the FDA regulation stated:

FDA believes that at least the following claims would be preempted by its regulation of prescription drug labeling: (1) Claims that a drug sponsor breached an obligation to warn by failing to put in Highlights or otherwise emphasize any information the substance of which appears anywhere in the labeling; (2) claims that a drug sponsor breached an obligation to warn by failing to include in an advertisement any information the substance of which appears anywhere in the labeling, in those cases where a drug's sponsor has used Highlights consistently with FDA draft guidance regarding the "brief summary" in direct-to-consumer advertising ...; (3) claims that a sponsor breached an obligation to warn by failing to include contraindications or warnings that are not supported by evidence that meets the standards set forth in this rule, including $\$ 201.57(\mathrm{c})(5)$ (requiring that contraindications reflect "[k]nown hazards and not theoretical possibilities") and (c)(7); (4) claims that a drug sponsor breached an obligation to warn by failing to include a statement in labeling or in advertising, the substance of which had been proposed to FDA for inclusion in labeling, if that statement was not required by FDA at the time plaintiff claims the sponsor had an obligation to warn (unless FDA has made a finding that the sponsor withheld material information relating to the proposed warning before plaintiff claims the sponsor had the obligation to warn); (5) claims that a drug sponsor breached an obligation to warn by failing to include in labeling or in advertising a statement the substance of which FDA has prohibited in labeling or advertising; and (6) claims that a drug's sponsor breached an obligation to plaintiff by making statements that FDA approved for inclusion in the drug's label (unless FDA has made a finding that the sponsor withheld material information relating to the statement).

Id. at 3935-36. 
that "[s]tate law actions also threaten FDA's statutorily prescribed role as the expert Federal agency responsible for evaluating and regulating drugs."44

As the FDA explained, its role in evaluating new drugs to determine their safety and efficacy was comprehensive. "Under the act, FDA is the expert Federal public health agency charged by Congress with ensuring that drugs are safe and effective, and that their labeling adequately informs users of the risks and benefits of the product and is truthful and not misleading." 45 It noted that in approving a new drug, the agency undertakes "a comprehensive scientific evaluation of the product's risks and benefits under the conditions of use prescribed, recommended, or suggested in the labeling." 46 The "FDA considers not only complex clinical issues related to the use of the product in study populations, but also important and practical public health issues pertaining to the use of the product in day-to-day clinical practice." 47 In particular, the FDA noted its careful attention to a product's labeling: "The centerpiece of risk management for prescription drugs generally is the labeling which reflects thorough FDA review of the pertinent scientific evidence and communicates to health care practitioners the agency's formal, authoritative conclusions regarding the conditions under which the product can be used safely and effectively."48

The FDA further noted that parallel state litigation could significantly interfere with the FDA's mission. As the FDA explained:

State law actions ... threaten FDA's statutorily prescribed role as the expert Federal agency responsible for evaluating and regulating drugs. State actions are not characterized by centralized expert evaluation of drug regulatory issues. Instead, they encourage, and in fact require, lay judges and juries to second-guess the assessment of benefits versus risks of a specific drug to the general public-the central role of FDA-sometimes on behalf of a single individual or group of individuals. That individualized reevaluation of the benefits and risks of a product can result in reliefincluding the threat of significant damage awards or penalties - that creates pressure on manufacturers to attempt to add warnings that FDA has neither

44 Id. at 3935 .

45 Id. at 3934 .

$46 \mathrm{Id}$.

${ }^{47} \mathrm{Id}$.

4871 Fed. Reg. at 3934 . The FDA noted that it "carefully controls the content of labeling for a prescription drug, because such labeling is FDA's principal tool for educating health care professionals about the risks and benefits of the approved product to help ensure safe and effective use." Id. "FDA continuously works to evaluate the latest available scientific information to monitor the safety of products and to incorporate information into the product's labeling when appropriate." Id. 
approved nor found to be scientifically required. This could encourage manufacturers to propose "defensive labeling" to avoid State liability, which, if implemented, could result in scientifically unsubstantiated warnings and underutilization of beneficial treatments. ${ }^{49}$

Among other things, the FDA concluded that state tort suits could "erode and disrupt the careful and truthful representation of benefits and risks that prescribers need to make appropriate judgments about drug use."50 In addition, they could "creat[e] pressure on manufacturers to expand labeling warnings to include speculative risks and, thus, to limit physician appreciation of potentially far more significant contraindications and side effects." 51 Finally, they could "discourag[e] safe and effective use of approved products or encourag[e] inappropriate use."52 The FDA maintained that there were "several instances in which product liability lawsuits have directly threatened the agency's ability to regulate manufacturer dissemination of risk information for prescription drugs." 53

\section{The Trial Record}

As the dissenters in Wyeth observed, the facts in the litigation plainly engendered sympathy for the plaintiff. Diana Levine had been treated for nausea following a migraine headache by a physician's assistant who administered Phenergan first via intramuscular injection and, after that failed to provide relief, using a "butterfly" intravenous infusion set, following a procedure known as "IV push" administration. ${ }^{54}$ As a result of this treatment, she suffered extensive damage to her arm, which became gangrenous and had to be amputated at the elbow. ${ }^{55}$ Plaintiff brought suit in Vermont state court alleging that defendant Wyeth had failed to appropriately warn of the hazards of intravenous injection of Phenergan, and after a five-day trial, a jury awarded her a verdict for $\$ 7,400,000$, which was adjusted downward to $\$ 6,774,000.56$

${ }^{49}$ Id. at 3935.

$50 \mathrm{Id}$.

51 Id.

5271 Fed. Reg. at 3935 ("Exaggeration of risk could discourage appropriate use of a beneficial drug.").

53 Id. at 3934.

${ }^{54}$ Levine v. Am. Home Prods., Inc., No. 670-12-01, 2004 WL 5456809, at *1 (Vt. Super. Ct. July 30,2004$)$.

$55 \mathrm{Id}$.

$56 \mathrm{Id}$. 
The evidence presented at trial indicated that there were essentially three methods for administering Phenergan: deep muscular injection, through a free-flowing IV bag, or through direct intravenous administration (the method used with plaintiff). ${ }^{57}$ Deep muscular injection and IV bag administration were shown to be less risky because the chance of accidentally administering Phenergan into an artery, which could lead to "catastrophic" tissue damage, ${ }^{58}$ is significantly reduced. Deep muscular injection largely avoids the arteries that could prove dangerous if accidentally accessed during administration. Administration through an IV bag drip is less risky because it is easier to determine if an artery has accidentally been tapped. Moreover, because there is back pressure from the patient, the IV solution containing Phenergan cannot flow into an artery. ${ }^{59}$

Given these alternative methods of administration, plaintiff argued that the direct intravenous method of administration should be strongly discouraged in the label or, at a minimum, should be accompanied with more significant warnings. ${ }^{60}$ The Phenergan label was not silent on this topic. Since 1976, it had contained a warning about the hazards of intra-arterial

${ }^{57} \mathrm{Id}$.

${ }^{58} \mathrm{Id}$. at $* 2$ (finding that when Phenergan is injected into arteries, "[t]he patient suffers spasm of the arteries, inflammation, loss of blood flow due to clotting, gangrene, and, in some cases, the loss of a limb or other serious injury" and that "[o]nce Phenergan enters the arterial flow, there is no reliable way to reverse the harmful effects of the medication on the tiny vessels distal (downstream) from the site of the injection"). Based on the evidence introduced at trial, the means by which Phenergan entered plaintiff's arteries was "unclear." Id. There was a possibility that the drug was administered "directly" into an artery or that the drug "leaked out of the vein and entered an artery through a process called extravasation." Levine, 2004 WL 5456809, at *2.

${ }^{59} \mathrm{Id}$. There was disagreement during the trial concerning whether the specific method of administration used in plaintiff's case was actually the less risky IV method or, rather, should be classified as a direct intravenous administration method. For example, defendant's expert testified that "the butterfly infusion set could be considered to be a form of free-flowing IV administration." Id. at *3. However, plaintiff's expert disagreed. See id.

${ }^{60} \mathrm{Id}$. at *1. For example, plaintiff's expert testified that "there was little medical justification for administration of Phenergan intravenously because of the availability of an intramuscular injection" and that "[i]f a physician chose intravenous administration of the drug, the use of a free-flowing IV bag would be safer than injection through a butterfly infusion set." Id. at *3. He concluded that "the warnings and instructions on the Phenergan label at the time of plaintiff's injury were inadequate to make the product safe because the defendant did not warn sufficiently of the risk of intravenous injection." Levine, 2004 WL 5456809, at *3; see also Levine v. Wyeth, 944 A.2d 179, 182 (Vt. 2008). 
injection. ${ }^{61}$ However, it did not specifically contain a warning or instruction "concerning the preferred use of an intravenous infusion set" for administration of the drug. ${ }^{62}$

In subsequent years, there were some proposals for revision of the label. However, the issue of intra-arterial injection came up only intermittently and does not appear to have been the subject of extensive discussion with the FDA. For example, an FDA advisory committee recommended in 1976 that the following warning be added: "If a Tubex system is used for intravenous injection, the drug should be injected into a satisfactorily functioning intravenous set." ${ }^{163}$ In 1981 and 1988, defendant proposed changing the package insert to contain the following language, which it submitted in conjunction with other proposed labeling changes: "When administering any irritant drug intravenously, it is usually preferable to inject it through the tubing of an intravenous infusion set that is known to be functioning satisfactorily." 64 However, this revised wording was not used. Finally, in

${ }^{61}$ Levine, 2004 WL 5456809, at *2. The FDA originally approved Phenergan in 1955. See Wyeth v. Levine, 129 S. Ct. 1187, 1191 (2009). In Wyeth, the Court noted the text of the 2000 version of the label:

Due to the close proximity of arteries and veins in the areas most commonly used for intravenous injection, extreme care should be exercised to avoid perivascular extravasation or inadvertent intra-arterial injection. Reports compatible with inadvertent intra-arterial injection of Phenergan Injection, usually in conjunction with other drugs intended for intravenous use, suggest that pain, severe chemical irritation, severe spasm of distal vessels, and resultant gangrene requiring amputation are likely under such circumstances. Intravenous injection was intended in all the cases reported but perivascular extravasation or arterial placement of the needle is now suspect. There is no proven successful management of this condition after it occurs. ... Aspiration of dark blood does not preclude intra-arterial needle placement, because blood is discolored upon contract with Phenergan Injection. Use of syringes with rigid plungers or of small bore needles might obscure typical arterial backflow if this is relied upon alone.... Phenergan Injection should be given in a concentration no greater than $25 \mathrm{mg}$ per $\mathrm{mL}$ and at a rate not to exceed 25 mg per minute. When administering any irritant drug intravenously it is usually preferable to inject it through the tubing of an intravenous infusion set that is known to be functioning satisfactorily. In the event that a patient complains of pain during intended intravenous injection of Phenergan Injection, the injection should be stopped immediately to provide for evaluation of possible arterial placement or perivascular extravasation.

Id. at $1191 \mathrm{n} .1$.

62 Levine, 2004 WL 5456809, at*3.

${ }^{63} \mathrm{Id}$.

${ }^{64} I d$. The Vermont Supreme Court identified the following provisions in the waming as relevant to the preemption analysis: 
1997, the FDA directed defendant to "retain verbiage in [the] current label" regarding intra-arterial injection and apparently rejected the language that defendant had proposed in 1981 and $1988 .{ }^{65}$

\section{The Trial Court's Analysis}

The Vermont trial court found that this evidence did not establish a sound case for preemption, and denied defendant's motion for summary judgment and post-trial motion for judgment as a matter of law. ${ }^{66}$ In summarizing this evidence, the court characterized it as demonstrating at most that the FDA gave the issue of whether IV infusion should be used to administer Phenergan only "passing attention:"

The evidence in this case is that a concern about inadvertent intra-arterial injection surfaced by 1979 and was the subject of a relatively mild warning proposed by the defendant in 1981 and again in 1988. The FDA rejected the proposed labeling change 9 years later in 1997 in a brief comment. There is no evidence in this record that either the FDA or the manufacturer gave more than passing attention to the issue of whether to use an IV infusion to administer the drug. The proposed labeling change did not address the use of a free-flowing IV bag. Viewing the matter in hindsight through the lens of a single catastrophic case, this Court heard little evidence that the FDA reviewed the issue of the intravenous administration of Phenergan with scientific rigor or any sense of urgency. ${ }^{67}$

INADVERTENT INTRA-ARTERIAL INJECTION: There are reports of necrosis leading to gangrene, requiring amputation, following injection of [Phenergan], usually in conjunction with other drugs; the intravenous route was intended in these cases, but arterial or partial arterial placement of the needle is now suspect. ...

There is no established treatment other than prevention:

1. Beware of the close proximity of arteries and veins at commonly used injection sites and consider the possibility of aberrant arteries.

2. When used intravenously, [Phenergan] should be given in a concentration no greater than $25 \mathrm{mg} / \mathrm{ml}$ and a rate not to exceed $25 \mathrm{mg} /$ minute. Injection through a properly running intravenous infusion may enhance the possibility of detecting arterial placement. In addition, this results in delivery of a lower concentration of any arteriolar irritant.

Wyeth, 944 A.2d at $183 \mathrm{n} .1$ (emphasis omitted).

${ }^{65}$ Levine, 2004 WL 5456809, at *3.

${ }^{66}$ Id. at *11.

${ }^{67}$ Id. at *6. 
Accordingly, the court concluded that " $[t]$ he record in this case does not indicate that the work of the FDA has been obstructed by the potential exposure of the manufacturer to state law tort liability."68

As is shown from the foregoing discussion, the court highlighted several aspects of the record in coming to this conclusion. First, there was a lack of evidence that the specific issue that was the subject of the controversy was actually raised with the FDA. ${ }^{69}$ The important issue in terms of the state-law tort suit was whether there could have been a stronger warning regarding use of IV-bag administration as the preferred means of administration compared with intravenous administration. The court did not find evidence that the FDA specifically considered this issue..$^{70}$ Moreover, it did not find strong evidence that the defendant manufacturer directly raised this issue with the FDA given the "relatively mild" nature of the warning contained in the proposed language submitted in 1981 and $1988 .{ }^{71}$ Second, the court noted the limited nature of the FDA's reaction to what had been submitted. The FDA did not take any action on the matter until nearly a decade later and then only dispensed with the proposed language in a cursory reference that did not, in the court's view, present any evidence that the FDA had actually considered the issue that came up in the state lawsuit. ${ }^{72}$

The trial court specifically contrasted this record with the record before the FDA in another case that had been cited by the parties involving medical devices. There, the FDA had engaged in "a comprehensive pre-market approval process" requiring "an average of 1,200 hours of review time by the agency, thousands of pages of documentation, and substantial give-and-take between the agency and the manufacturer." 73 The court found this contrast significant:

That is a very different process from the leisurely course of review for the Phenergan label changes conducted over some sixteen years. The regulatory process in this case was marked by long periods of dormancy and a conclusory decision in 1997 to require no change to the existing label. The recommendation of administration through a free-flowing IV bag never appears in the regulatory record. ${ }^{74}$

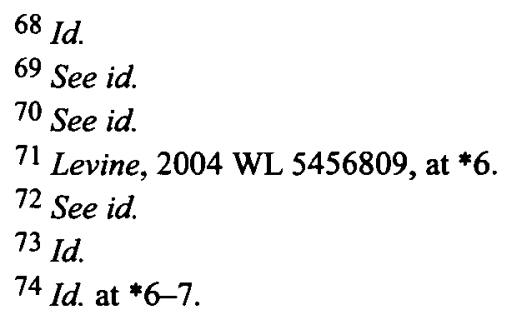


"In short, a tort case is unlikely to obstruct the regulatory process when the record shows that the FDA has paid very little attention to the issues raised by the parties at trial." 75

Indeed, the court questioned whether there even could have been any reason that the FDA would not have ordered a stronger warning if it had actually considered the issue. It found that there was no risk that "excessive or unwarranted" rulings regarding "remote" side effects might reduce the use of a safe and effective treatment because the question in the Phenergan case "relates only to the method of administration" of the drug and "not to the decision to use Phenergan" in the first instance. ${ }^{76}$ It was thus much different than the case of a pharmaceutical product where there was a question concerning whether additional warnings should be provided. In such circumstances, the court noted, the case for preemption was much stronger given that "proposed warnings of remote side effects ... might dissuade physicians from using the drug to the detriment of the patient population."77

\section{E. The Vermont Supreme Court's Analysis}

The Vermont Supreme Court agreed with the trial court that this was not a particularly good case for application of the preemption doctrine. ${ }^{78}$ On appeal, defendant Wyeth crafted two primary theories in arguing that the state tort suit conflicted with FDA actions. ${ }^{79}$ First, it maintained that there was a conflict because the FDA was aware of the dangers of the IV-push method of administration and yet had specifically ordered defendant to continue using a label that lacked warnings that plaintiff maintained were necessary to convey the risks. ${ }^{80}$ Second, defendant maintained that allowing the state tort claims to proceed would present an obstacle to the purpose of the FDA's labeling regulations by allowing juries in the various state jurisdictions to impose different standards concerning the appropriate warnings in the Phenergan label. ${ }^{81}$

${ }^{75} I d$. at *7.

${ }^{76} \mathrm{Id}$.

${ }^{77}$ Levine, 2004 WL 5456809, at*7.

${ }^{78}$ Levine v. Wyeth, 944 A.2d 179, 182 (Vt. 2006).

${ }^{79} \mathrm{Id}$. at 185 . Wyeth also asserted a related theory of field preemption, which it subsequently abandoned. See English v. Gen. Elec. Co., 496 U.S. 72, 79 n.5 (1990) (observing that "field pre-emption may be understood as a species of conflict preemption").

${ }^{80}$ Wyeth, 944 A.2d at 185.

81 See id. 
Under longstanding Supreme Court precedent, "it has been settled that state law that conflicts with federal law is "without effect." 82 This requirement flows directly from the Supremacy Clause in Article IV of the Constitution. ${ }^{83}$ The doctrine of conflict preemption encompasses both " "conflicts' that prevent or frustrate the accomplishment of a federal objective" and "'conflicts' that make it 'impossible' for private parties to comply with both state and federal law." 84 Defendant thus invoked both prongs of the doctrine (as well as certain other preemption theories) in challenging the state court judgment.

While the Chief Justice of that court filed a strong dissent, it was largely based on his dispute of the majority's characterization of the plaintiff's claims in the underlying lawsuit. Chief Justice Reiber argued that recovery by the plaintiff would entail a refutation of the FDA's decision not to bar the IV-push method of administration of Phenergan. ${ }^{85}$ The majority rejected this contention, however, concluding that the only issue was the content of the warnings in the Phenergan labeling and that the FDA record did not demonstrate that the agency had thoroughly considered this issue in approving the wording in the label. ${ }^{86}$

\section{The Majority's Analysis}

The majority's analysis relied heavily on the Changes Being Effected regulation found in 21 C.F.R. $\S 314.70$ (c), which it concluded "creates a specific procedure allowing drug manufacturers to change labels that are insufficient to protect consumers, despite their approval by the FDA," thereby allowing "manufacturers to avoid state failure-to-warn claims

82 Cipollone v. Liggett Group, Inc., 505 U.S. 504, 516 (1992) (quoting Maryland v. Louisiana, 451 U.S. 725, 746 (1981)).

83 The Supremacy Clause provides that: "This Constitution, and the Laws of the United States which shall be made in Pursuance thereof; and all Treaties made, or which shall be made, under the Authority of the United States, shall be the supreme Law of the Land; and the Judges in every State shall be bound thereby, any Thing in the Constitution or Laws of any State to the Contrary notwithstanding." U.S. CONST. art. VI, cl. 2; see also Lorillard Tobacco Co. v. Reilly, 533 U.S. 525, 540-41 (2001) (Supremacy Clause allows Congress to "pre-empt[] state action in a particular area"); Fid. Fed. Sav. \& Loan Ass'n v. de la Cuesta, 458 U.S. 141, 152 (1982) (preemption doctrine "has its roots in the Supremacy Clause"); Caleb Nelson, Preemption, 86 VA. L. REV. 225, 252 (2000) ("Under the Supremacy Clause, any obligation to disregard state law flows entirely from the obligation to follow federal law.").

84 Geier v. Am. Honda Motor Co., 529 U.S. 861, 873-74 (2000).

85 See Wyeth, 944 A.2d at 197 (Reiber, C.J., dissenting).

${ }^{86}$ See id. at 198. 
without violating federal law." 87 Accordingly, in the majority's view, there was no necessary conflict with FDA regulation or absolute prohibition on state failure-to-warn claims. Rather, the analysis was more nuanced. The court concluded that it must look at the specific record in the case to determine whether it created an actual conflict between the FDA and the state failure-to-warn lawsuit. ${ }^{88}$

In doing so, it rejected a couple of arguments raised by the defendant in support of its interpretation. First, it concluded that the Supreme Court's decision in Buckman Co. v. Plaintiffs' Legal Committee ${ }^{89}$ was not controlling because that decision held that so-called "fraud-on-the-FDA" claims were preempted in a case involving medical devices..$^{90}$ The court distinguished that decision on the ground that fraud-on-the-FDA claims did not fall within an area of traditional state authority, whereas failure-to-warn claims did. ${ }^{91}$ Second, the Court rejected defendant's argument that Geier v. American Honda Motor Co. ${ }^{92}$ compelled a contrary result. Geier involved a regulation governing safety standards for automobiles. Defendant there successfully argued that the federal regulations preempted state-law tort claims for failure of manufacturers to produce automobiles without airbags. ${ }^{93}$ However, the Vermont Supreme Court distinguished Geier on the ground that, in its view, the regulation there was specifically designed to impose a ceiling, and not merely a floor, for state regulation..$^{94}$ The court noted that the record in Geier indicated that "the Department of Transportation's intent in drafting the regulation at issue was to provide a range of different safety options, thus precluding any state determination that a specific type of equipment should be required." 95 The court contrasted this with the FDA's regulations, which it interpreted as specifically authorizing manufacturers to adopt more stringent

${ }^{87} \mathrm{Id}$. at $185-86$ (majority opinion).

$88 \mathrm{See}$ id. at 188 ("FDA approval of a particular label does not preempt a jury finding that the label provided insufficient warning, as defendant was free under $\S 314.70$ (c) to strengthen the warning without prior FDA approval.").

89531 U.S. 341, 341 (2001).

90 Wyeth, 944 A.2d at 187.

$91 \mathrm{Id}$.

92529 U.S. 861 (2000). For a discussion of Geier, see Richard C. Ausness, Preemption of State Tort Law By Federal Safety Statutes: Supreme Court Preemption Jurisprudence Since Cipollone, 92 KY. L.J. 913, 955-59 (2004); Alexander K. Haas, Chipping Away at State Tort Remedies Through Pre-emption Jurisprudence: Geier v. American Honda Motor Co., 89 CAL. L. REV. 1927 (2001).

93 See Geier, 529 U.S. at 861.

94 Wyeth, 944 A.2d at 188.

95 Id. at 187. 
warnings without FDA approval, thereby ruling out any possibility that state failure-to-warn lawsuits were automatically preempted. ${ }^{96}$

In so ruling, the Vermont Supreme Court specifically contrasted certain decisions that had been issued in the litigation regarding the antidepressant Zoloft. ${ }^{97}$ There, the court observed, there had been "an FDA statement that the warning advocated by the plaintiff would have been misleading." 98 Under such circumstances, there was an actual conflict manifested in the record between the state failure-to-warn claims and the FDA's action. Thus, the court did not hold that failure-to-warn claims were never preempted, but rather that they were not always preempted simply by virtue of the fact that the FDA had approved a drug's labeling.

Applying these principles to the facts in Wyeth, the court found that the record did not manifest an overt conflict between the FDA's action and the state failure-to-warn claim. The court found, for example, that " $[t]$ he record lacks any evidence that the FDA was concerned that a stronger warning was not supported by the facts, that such a stronger warning would distract doctors from other provisions in the drug's label, or that the warning might lead to less effective administration of the drug." 99 Likewise, the court found that while "Defendant has provided a number of letters exchanged by the FDA and defendant regarding Phenergan's label," the letters "do not indicate the FDA's opinion of the value of IV-push administration," or in particular that "the FDA wished to preserve the use of IV push as a method of administering Phenergan."100 This included defendant's assertion that the FDA's rejection of its proposed labeling changes suggested that the FDA had concluded that no further warnings regarding the IV-push method were warranted:

The FDA could have rejected the new warning for any number of reasons, including clarity or technical accuracy, without implicitly prohibiting a stronger warning. Defendant's unsupported hypothesis that the FDA saw the new warning as harmful seems among the least likely explanations, as

96 See id. at 188.

97 See id. at 186-87 (citing Needleman v. Pfizer, Inc., No. Civ. A. 3:03-CV-3074-N 2004 WL 1773697, at *1 (N.D. Tex. Aug. 6, 2004)).

98 Id. at 187.

${ }^{99}$ Id. at 188 .

100 Wyeth, 944 A.2d. at 189. 
the rejected proposal would not have eliminated IV push as an option for administering Phenergan. 101

Accordingly, based on the majority's view of the record, there was no conflict between FDA action and the failure-to-warn claim, and thus no preemption.

The majority rejected defendant's argument that the state lawsuit was inconsistent with congressional purposes and objectives for similar reasons. ${ }^{102}$ The majority pointed to the 1962 amendments to the FDCA as evidencing a congressional intent that state-law tort suits not be preempted in every case, finding that "Congress intended that the FDCA would leave state law in place except where it created a 'direct and positive conflict' between state and federal law."103 It held that this legislative statement defeated defendant's allegation that state-law tort suits per se interfered with congressional purposes and objectives given that Congress expressly contemplated that there was room for the continued effect of state law in this area. ${ }^{104}$ While it noted the important concern that "permitting too much state activity in this area will make beneficial drugs less available to consumers," 105 it concluded that such policy concerns could not trump the clear expression of congressional intent. Likewise, it concluded that the FDA's recent statement on the preemptive effect of the FDCA could not change what the court believed was the intent expressed by Congress:

Here, we are not attempting to infer the effect of statutory language that only indirectly addresses the specific state law at issue. Instead, we are interpreting an unambiguous express preemption clause that specifically preserves the type of state law at issue. Under these circumstances, ordinary preemption principles must give way to Congress's intent to preserve state laws that do not create a "direct and positive conflict" with federal law. Drug Amendments $\S 202$. There is no such conflict here. Accordingly, the FDA's statement is neither an authoritative interpretation of an ambiguous statutory provision entitled to deference, Chevron, 467 U.S. at $842-43$,

$101 \mathrm{Id}$. The majority also concluded that "the proposed warning was different, but not stronger." Id. "It was also no longer or more prominent than the original warning, so it could not have raised a concern that it might overshadow other warnings on the label or drive doctors away from prescribing the drug." Id.

102 Id. at 190.

103 Id.

104 Wyeth, 944 A.2d at 191.

$105 \mathrm{Id}$. at 191. 
104 S.Ct. 2778, nor a persuasive policy statement entitled to respect. Mead, 533 U.S. at 235,121 S. Ct. $2164{ }^{106}$

According to the majority, the FDA did not adequately explain "the inconsistency between its position and the language of the [congressional] preemption amendment."107

\section{The Dissent}

Chief Justice Reiber issued a strong dissent, agreeing with defendants that the state law claims were preempted based both on the existence of a conflict with FDA regulation of Phenergan and also because they would obstruct federal purposes and objectives. With respect to the first grounds for preemption, Chief Justice Reiber maintained that plaintiff's lawsuit essentially sought to eliminate a means of administration-IV-push administration - that the FDA had expressly approved:

Specifically, the FDA approved IV administration of Phenergan and required that IV administration be listed on the Phenergan label. By contrast, plaintiff's theory of the case required Wyeth either to remove this approved use from the Phenergan label, add a warning that would directly contradict the label's indication that IV administration was a safe and effective use, or, at a minimum, add a warning that only certain types of IV administration should be used. Thus, compliance with state law in this case would require Wyeth to eliminate uses of Phenergan approved by the FDA and required to be included in the Phenergan labeling. ${ }^{108}$

106 Id. at 193-94. Accordingly, the Court concluded: "Nothing in the FDA's new statement alters our conclusion that it would be possible for defendant to comply with both its federal obligations and the obligations of state common law." Id. at 193.

107 Id. at 193.

${ }^{108}$ Id. at 197 (Reiber, C.J., dissenting). The dissent further stated:

The majority in essence concludes that it is not impossible for Wyeth to comply with both federal and state standards because Wyeth never sought FDA approval of a "stronger warning" of the type advocated by plaintiff. According to the majority, because the FDA was not presented with, and therefore did not explicitly reject, such strengthened language, there is no reason to presume that the FDA would disapprove. Therefore, the majority reasons, there is no actual conflict between state and federal law.... It is inaccurate, however, to characterize the requirements imposed by the jury verdict in this case as merely requiring a "stronger warning." Rather, what plaintiff sought was an elimination of a use of Phenergan that had been approved by the FDA. Furthermore, the FDA's rejection of Wyeth's efforts to alter 
Accordingly, there was a direct conflict between the state lawsuit and FDA regulation. This view of the nature of the plaintiff's claim rendered the FDA's CBE regulation largely irrelevant given that, under Section 314.70(c), "a manufacturer may change a label only to add or strengthen a warning, not to eliminate an approved use."109

For similar reasons, Chief Justice Reiber found that the state lawsuit would impose obstacles to federal purposes and objectives because it would essentially vitiate the FDA's approval of a particular means of drug administration:

In short, by approving Phenergan for marketing and distribution, the FDA concluded that the drug - with its approved methods of administration and as labeled - was both safe and effective.... In finding defendant liable for failure to warn, a Vermont jury concluded that the same drug-with its approved methods of administration and as labeled-was "unreasonably dangerous."... These two conclusions are in direct conflict. ${ }^{110}$

The dissent rejected the notion that the 1962 "preemption amendment" barred this theory, arguing that its language regarding "direct and positive conflict[s]" did not have anything to do with "the 'obstacle' prong of the actual conflict preemption standard." 111 Rather, it believed that the case was similar to the situation the Supreme Court addressed in Geier, reasoning that, "[a]s with the DOT in Geier, the FDA is primarily concerned with public safety" and that in approving drug labeling "the FDA balances its assessment of a drug's safety against concerns for the drug's efficacy, taking into account that a safer but less effective drug is not necessarily best for the public health overall."112

the language of the waming in 2000 supports Wyeth's claim that the FDA had an affirmative preference for the language of the original warning.

Wyeth, 944 A.2d. at 197-98 (Reiber, C.J., dissenting).

${ }^{109} \mathrm{Id}$. at 199. The dissent also argued that "the regulation does not allow manufacturers to simply reassess and draw different conclusions regarding the same risks and benefits already balanced by the FDA" and that "[h]ere, the FDA had already evaluated the risk of inadvertent arterial injection from direct IV administration of Phenergan, and had mandated warning language for the label to reflect that risk assessment." Id. In addition, the dissent argued that "any change accomplished under $\S 314.70$ (c) is subject to ultimate FDA review and approval." Id.

110 Id. at 197 (citation omitted).

111 Id. at 201.

112 Wyeth, 944 A.2d. at 202-03 (Reiber, C.J., dissenting). 
State tort lawsuits would interfere with such reasoned decision making and balancing of competing considerations regarding what to include and what to exclude in pharmaceutical product labeling. As the dissent explained:

No drug is without risks. The FDA balances the risks of a drug against its benefits to maximize the availability of beneficial treatments. The FDA's decision in approving a drug, its uses and labeling reflect consideration of these and other policy factors. While a state-court jury presumably shares the FDA's concern that drugs on the market be reasonably safe, the jury does not assess reasonableness in the context of public health and the associated risk-benefit analysis. A jury does not engage in a measured and multi-faceted policy analysis. Rather, a jury views the safety of the drug through the lens of a single patient who has already been catastrophically injured. Such an approach is virtually guaranteed to provide different conclusions in different courts about what is "reasonably safe" than the balancing approach taken by the FDA. In fact, different conclusions were reached in this case. 113

The dissent concluded that the jury's verdict "conflict[ed] squarely with the FDA's assessment of precisely the same issue" and thereby frustrated the reasoned federal process that was designed to resolve such questions. ${ }^{114}$

Thus, there was a fundamental disagreement between the dissent and the majority that was largely based on how plaintiff's claims were characterized. While the majority viewed this as a straightforward failure-to-warn case, the dissent found that "[ $t]$ he crux of plaintiff's claim was not based on the label warnings per se, but on the approved uses listed there." 115 Largely, this dispute turned on whether the FDA's references to "IV administration" meant that it had specifically considered the safety and effectiveness of IVpush administration, or whether this generic term merely referred to all forms of IV administration, including the IV-drip administration that plaintiff argued was a safer means of administration. ${ }^{116}$

113 Id. at 203 (Reiber, C.J., dissenting).

114 Id.

$115 \mathrm{Id}$. at 198. As the dissent further observed: "At its core, plaintiff's argument in this case was not that the warnings on the label were inadequate, but that an approved use (direct IV administration) was in fact unreasonably unsafe. Plaintiff did not seek to 'add or strengthen' a warning or a dosage/administration instruction, but rather to eliminate an approved use of the drug." Id. at 200.

116 In rejecting the assertion that the lawsuit sought to ban a method of administration that had been specifically approved by the FDA, the majority reasoned as follows: 


\section{THE SUPREME COURT's DECISION}

To the surprise of many, the United States Supreme Court affirmed the Vermont Supreme Court's ruling. Nonetheless, it suggested that its ruling was a "narrow" one that was limited to its specific facts. ${ }^{117}$ Moreover, both the majority and Justice Breyer's concurrence suggested ways in which the preemption doctrine may serve an important role in future cases with stronger facts demonstrating an actual conflict between state tort claims and FDA regulation of pharmaceutical products.

\section{A. The Majority Opinion}

The majority in Wyeth adopted the premise of the majority opinion issued by the Vermont Supreme Court-i.e., that the Vermont jury verdict against Wyeth did not require the contraindication of IV-push administration of Phenergan, but rather only found that the warning was insufficient in some manner. ${ }^{118}$ It likewise relied heavily on the CBE regulations in concluding that FDA regulation did not conflict with the state-law tort claims. While it recognized that "the FDA retains authority to reject labeling changes made pursuant to the CBE regulation in its review of the manufacturer's

The dissent appears to interpret any warning that would eliminate IV-push administration as inherently inconsistent with the FDA's approval of Phenergan for IV administration in general. We see no such inconsistency, as an approval of a drug for IV administration is not the same as a conclusion that all methods of IV administration are safe. In any case, a jury verdict in a failure-to-warn case simply establishes that the relevant warning was insufficient; it does not mandate a particular replacement waming.

Id. at $189 \mathrm{n} .2$ (majority opinion). In contrast, the dissent stated:

Here, the FDA clearly addressed the risks attending IV administration of the drug. The label approved IV administration generally, and specifically warned of the dangers of direct IV administration, including inadvertent arterial injection possibly resulting in amputation. In light of this, it cannot be argued that the FDA did not (1) assess the risk of IV administration, including direct IV administration and the associated risk of amputation due to inadvertent arterial injection; (2) conclude that the benefits of allowing IV administration with appropriate warnings outweighed the risk; and (3) reach a decision regarding precisely what warning language should be used.

Wyeth, 944 A.2d. at 198 (Reiber, C.J., dissenting).

117 Wyeth v. Levine, 129 S.Ct. 1187, 1194 (2009) ("The narrower question presented is whether federal law pre-empts Levine's claim that Phenergan's label did not contain an adequate warning about using the IV-push method of administration.").

118 Id. 
supplemental application,"119 nonetheless, manufacturers remained free to strengthen the warnings in the labeling in the first instance. Accordingly, the Court held that "absent clear evidence that the FDA would not have approved a change to Phenergan's label, we will not conclude that it was impossible for Wyeth to comply with both federal and state requirements."120

The majority found that there was "no such evidence" in the record before it. ${ }^{121}$ The Court observed that while Wyeth had argued that the FDA had in fact considered the need for strengthened warnings regarding the IVpush method of administration, "both the trial court and the Vermont Supreme Court rejected this account as a matter of fact," finding "no evidence in this record that either the FDA or the manufacturer gave more than passing attention to the issue of IV-push versus IV-drip administration."122 In particular, the majority rejected the notion that the FDA's rejection of the 1988 warning constituted consideration of the particular risks at issue in the Vermont lawsuit. The majority observed that "the trial court and the Vermont Supreme Court found that the 1988 warning did not differ in any material respect from the FDA-approved warning"123 and found that "the United States concedes that the FDA did not regard the proposed warning as substantively different." 124 Indeed, the majority found that "Wyeth does not argue that it supplied the FDA with an evaluation or analysis concerning the specific dangers posed by the IV-push method." 125

Thus, because there had been no consideration of the particular risks that were at issue in the state lawsuit, as a matter of fact, there could be no conflict between the FDA's action and the outcome of that lawsuit, and thus, in the majority's opinion, no preemption. As the majority explained, "the mere fact that the FDA approved Phenergan's label" was insufficient to establish preemption:

On the record before us, Wyeth has failed to demonstrate that it was impossible for it to comply with both federal and state requirements. The CBE regulation permitted Wyeth to unilaterally strengthen its warning, and

119 Id. at 1198 .

$120 \mathrm{Id}$.

$121 \mathrm{Id}$.

${ }^{122} I d$. at 1198-99 (internal quotes omitted).

123 Wyeth, 129 S. Ct. at 1199 n.5 (citing Wyeth, 944 A.2d 179, 189 (Vt. 2006)).

124 Id. (citing Brief for the United States as Amicus Curiae Supporting Petitioner at 25, Wyeth v. Levine, No. 06-1249 (U.S. 2009)).

125 Id. at 1199. The Court therefore found that it "cannot credit Wyeth's contention that the FDA would have prevented it from adding a stronger warning about the IV-push method of intravenous administration." Id. 
the mere fact that the FDA approved Phenergan's label does not establish that it would have prohibited such a change. ${ }^{126}$

The test applied by the Court thus requires a far more fact-intensive analysis regarding the actual record regarding a pharmaceutical's approval and subsequent review by the FDA.

The majority was more firm in rejecting Wyeth's second theory that state-law failure-to-warn claims would obstruct the purposes and objectives of federal drug labeling regulation. The Court concluded that congressional intent was to the contrary, given that Congress had never expressly preempted state-law tort suits, as it had in the context of medical devices. ${ }^{127}$ In addition, it rejected Wyeth's reliance on the 2006 FDA regulation, concluding that it did not "merit deference," given that the agency finalized its rule "without offering States or other interested parties notice or opportunity for comment," which the Court believed rendered the regulation "inherently suspect."128 It thus contrasted the situation with that in Geier, which it found to be "quite different" because in that case the Department of Transportation had conducted a "formal rulemaking."129 Moreover, the majority concluded that the regulations were inconsistent with its view of the congressional record, which it concluded manifested no intent to impose an across-the-board rule of preemption of state failure-to-warn claims. ${ }^{130}$

${ }^{126} \mathrm{Id}$.

${ }^{127}$ Id. at 1200 (citing Federal Food, Drug and Cosmetic Act, 21 U.S.C. $\$ 360$ k(a) (2006)). The majority noted that congressional "silence on the issue, coupled with its certain awareness of the prevalence of state tort litigation, is powerful evidence that Congress did not intend FDA oversight to be the exclusive means of ensuring drug safety and effectiveness." Wyeth, $129 \mathrm{~S}$. Ct. at 1200 . The express preemption provision of the Medical Device Amendments to the FDCA states as follows:

$[\mathrm{N}] \mathrm{o}$ State ... may establish or continue in effect with respect to a device intended for human use any requirement-(1) which is different from, or in addition to, any requirement applicable under this chapter to the device, and (2) which relates to the safety or effectiveness of the device or to any other matter included in a requirement applicable to the device under this chapter.

21 U.S.C. $\S 360 \mathrm{k}(\mathrm{a})$.

128 Wyeth, 129 S. Ct. at 1201.

${ }^{129} \mathrm{Id}$. at 1203 (citing Geier, 529 U.S. at $875,879,881$ ). The Court also found the amicus brief filed by the U.S. government in support of Wyeth's position was "undeserving of deference" because it was inconsistent with prior "understanding" of the scope of the preemptive effect of its regulations. See id. at 1203 n.13.

$130 \mathrm{See} i \mathrm{~d}$. at $1200-04$. The majority also noted that the 2006 FDA statement "represents a dramatic change in position," id. at 1203, and "reverses the FDA's own longstanding position without providing a reasoned explanation, including any discussion 
However, the Court inferred this congressional intent largely through congressional silence, noting that Congress had not chosen to expressly preempt state failure-to-warn lawsuits. ${ }^{131}$ Moreover, it further noted that "some state-law claims might well frustrate the achievement of congressional objectives," simply stating that "this is not such a case."132 Accordingly, again the majority's rationale seems particularly limited to the case's unique facts.

\section{B. Justice Breyer's Concurrence}

Justice Breyer's concurrence underscores this aspect of the majority's decision, at least with respect to the obstruction of federal goals prong of the preemption analysis. Justice Breyer emphasized the fact that the preamble to the FDA regulations regarding preemption had not been subjected to notice and comment rulemaking. He noted that it was "possible that state tort law will sometimes interfere with the FDA's desire to create a drug label containing a specific set of cautions and instructions," that "state tort law can sometimes raise prices to the point where those who are sick are unable to obtain the drugs they need," and that the FDA might seek to embody determinations regarding when state tort law "acts as a help or a hindrance to achieving the safe drug-related medical care ... in lawful specific regulations describing, for example, labeling when requirements serve as a ceiling as well as floor." 133 Accordingly, Justice Breyer wrote separately to underscore that "it is possible that such determinations would have pre-emptive effect." 134

of how state law has interfered with the FDA's regulation of drug labeling during decades of coexistence," id. at 1201; see also id. at 1202-03 ("Failure-to-warn actions, in particular, lend force to the FDCA's premise that manufacturers, not the FDA, bear primary responsibility for their drug labeling at all times. Thus, the FDA long maintained that state law offers an additional, and important, layer of consumer protection that complements FDA regulation.").

131 Wyeth, 129 S. Ct. at 1204 ("Congress has repeatedly declined to pre-empt state law, and the FDA's recently adopted position that state tort suits interfere with its statutory mandate is entitled to no weight.").

132 Id.

133 Id. at 1204 (Breyer, J., concurring).

134 Id. 


\section{Justice Thomas's Concurrence}

Justice Thomas's concurrence, in contrast, offered a far more restrictive view regarding preemption that was motivated by his particular views regarding the importance of federalism. Justice Thomas reiterated that he had become "increasingly skeptical of th[e] Court's 'purposes and objectives' pre-emption jurisprudence." $135 \mathrm{He}$ believed that the Court's precedents were so broad that they often led to courts invalidating state laws based on "perceived conflicts with broad federal policy objectives, legislative history, or generalized notions of congressional purposes."136

In Justice Thomas's view, this broad approach to preemption had eroded the traditional role of the states vis-à-vis the federal government. In particular, he was concerned with relying upon legislative history or agency statements to preempt state law given that such pronouncements did not have the force of law under the Supremacy Clause. ${ }^{137}$ Rather, he would more rigidly adhere to the text and structure of congressional statutes in determining whether they preempted inconsistent state law. ${ }^{138}$ According to Justice Thomas, "[p]re-emption must turn on whether state law conflicts with the text of the relevant federal statute or with the federal regulations authorized by that text." 139

He therefore joined the majority because "the text of the relevant federal statutory provisions and the corresponding regulations do not directly conflict with the state-law judgment before us." 140 Here, Justice Thomas found the text of the FDA's CBE regulation dispositive:

Under the FDA's "changes being effected" regulation, 21 C.F.R. $\S 314.70$ (c)(6)(iii), which was promulgated pursuant to the FDA's statutory authority, it is physically possible for Wyeth to market Phenergan in compliance with federal and Vermont law. As the majority explains, Wyeth could have changed the warning on its label regarding IV-push without violating federal law... The "changes being effected" regulation allows drug manufacturers to change their labels without the FDA's preapproval if the changes "add or strengthen a contraindication, warning, precaution, or adverse reaction," $\S 314.70(\mathrm{c})(6)(\mathrm{iii})(\mathrm{A}), \ldots$ in order to "reflect newly acquired information," including "new analyses of previously submitted

135 Id. at 1205 (Thomas, J., concurring in the judgment).

136 Id.

137 Wyeth, 129 S. Ct. at 1205 (Thomas, J., concurring in the judgment.).

138 See id.

$139 \mathrm{Id}$. at 1208.

140 Id. 
data," 73 Fed.Reg. 49603, 49609. Under the terms of these regulations, after learning of new incidences of gangrene-induced amputation resulting from the IV-push administration of Phenergan ..., federal law gave Wyeth the authority to change Phenergan's label to "strengthen a ... warning," "strengthen a ... precaution," $\S 314.70(\mathrm{c})(6)(\mathrm{iii})(\mathrm{A})$, or to "strengthen an instruction about ... administration [of the IV-push method] . . to increase the safe use of the drug product," $\S 314.70(c)(6)(i i i)(C)$. Thus, it was physically possible for Wyeth to comply with a state-law requirement to provide stronger warnings on Phenergan about the risks of the IV-push administration method while continuing to market Phenergan in compliance with federal law. 141

Thus, Justice Thomas agreed with the majority that there was no preemption. However, his rigid textualist approach differs dramatically from that of the majority, which delved deeply into the facts and circumstances of the FDA record to make a highly factual determination regarding whether the FDA had actually considered the particular risks that were at issue in the state tort litigation. Indeed, his analysis of the Court's precedents demonstrates how broad they really are and how they depend in large part on the particular facts and circumstances of an individual case. ${ }^{142}$ There is simply no one-size-fits-

$141 \mathrm{Id}$. at $1209-10$ (alterations in original). Like the majority, Justice Thomas agreed that "[i]nitial approval of a label amounts to a finding by the FDA that the label is safe for purposes of gaining federal approval to market the drug. It does not represent a finding that the drug, as labeled, can never be deemed unsafe by later federal action, or as in this case, the application of state law." Id. at 1210.

142 According to Justice Thomas: "The cases improperly rely on legislative history, broad atextual notions of congressional purpose, and even congressional inaction in order to pre-empt state law." Wyeth, 129 S. Ct. at 1211 (Thomas, J., concurring in the judgment). Accordingly, he declined to "join the majority's analysis of this claim." Id. Justice Thomas was particularly critical of the Court's decision in Geier:

The Court's decision in Geier to apply "purposes and objectives" pre-emption based on agency comments, regulatory history, and agency litigating positions was especially flawed, given that it conflicted with the plain statutory text of the saving clause within the Safety Act, which explicitly preserved state common-law actions by providing that "[c]ompliance with any Federal motor vehicle safety standard issued under this subchapter does not exempt any person from any liability under common law," 15 U.S.C. § 1397(k).

Id. at 1214. "Applying 'purposes and objectives' pre-emption in Geier, as in any case, allowed this Court to vacate a judgment issued by another sovereign based on nothing more than assumptions and goals that were untethered from the constitutionally enacted federal law authorizing the federal regulatory standard that was before the Court." Id. at 1215. 
all approach in determining whether state action is preempted. Rather, each case must be assessed on its own merits.

\section{The Dissenting Opinion}

Justice Alito's dissent, which was joined by Justice Scalia, likewise illustrates the highly factual nature of the preemption analysis after Wyeth. The dissent fundamentally differed regarding critical facts in the record. Most importantly, it found that "it is demonstrably untrue that the FDA failed to consider (and strike a 'balance' between) the specific costs and benefits associated with IV push."143 Rather, it maintained that "the record contains ample evidence that the FDA specifically considered and reconsidered the strength of Phenergan's IV-push-related warnings in light of new scientific and medical data."144 It proceeded to catalogue several points in the more than fifty-year regulatory history of Phenergan where the FDA arguably considered or addressed the risk of IV-push administration. ${ }^{145}$ Moreover, while it noted that it was irrelevant to the outcome of its analysis, ${ }^{146}$ the dissent believed that the continued use of the IV-push method of administration was essentially at issue in the case given that the jury verdict inherently involved a finding that this method of administration was unsafe. ${ }^{147}$

Accordingly, the dissent concluded that the case was essentially identical to Geier. The dissent noted that, despite the fact that the statute at issue in

143 Wyeth, 129 S. Ct. at 1222 (Alito, J., dissenting); see also id. at 1218 ("The FDA has long known about the risks associated with IV push in general and its use to administer Phenergan in particular.").

144 Id. at 1222; see also id. at 1226 ("[W]hatever else might be said about the extensive medical authorities and case reports that the FDA cited in 'support' of its approval of IV-push administration of Phenergan, it cannot be said that the FDA 'paid no more than passing attention to' IV push ...; nor can it be said that the FDA failed to weigh its costs and benefits.").

145 See id. at 1222-24.

146 The dissent explained that "the degree of a State's intrusion upon federal law is irrelevant." Id. at 1227.

147 See Wyeth, 129 S. Ct. at 1218 (Alito, J., dissenting) ("[T]he question presented by this case is not a 'narrow' one, and it does not concern whether Phenergan's label should bear a 'stronger' waming. Rather, the real issue is whether a state tort jury can countermand the FDA's considered judgment that Phenergan's FDA-mandated warning label renders its intravenous (IV) use 'safe."'). In particular, the dissent pointed to the allegations in the complaint and testimony during trial that made clear that the plaintiff was alleging that the IV-push method of administration was unsafe as well as the trial judge's charge to the jury. Id. at $1218 \&$ n. 2 . 
Geier had a savings clause stating that compliance with standards issued under the federal statute did not preclude liability under the common law and despite the fact that the Department of Transportation had authority only to issue "minimum" safety standards, the Court had held that the state-law tort suit was preempted. ${ }^{148}$ "Because the Secretary determined that a menu of alternative technologies was 'safe,' the doctrine of conflict pre-emption barred Geier's efforts to deem some of those federally approved alternatives 'unsafe' under state tort law." 149 The dissent believed that the facts with respect to Phenergan were analogous:

Through Phenergan's label, the FDA offered medical professionals a menu of federally approved, "safe" and "effective" alternatives-including IV push-for administering the drug. Through a state tort suit, respondent attempted to deem IV push "unsafe" and "ineffective." To be sure, federal law does not prohibit Wyeth from contraindicating IV push, just as federal law did not prohibit Honda from installing airbags in all its cars. But just as we held that States may not compel the latter, so, too, are States precluded from compelling the former. ${ }^{150}$

In fact, the dissent believed that preemption was "even more appropriate" in the context of pharmaceutical products given that there was no savings clause under the FDCA and there was "no evidence" that Congress intended that the FDA "set only "minimum standards."'151 Moreover, it faulted the majority for essentially ignoring "the FDA's explanation of the conflict between state tort suits and the federal labeling regime, set forth in the agency's amicus brief...."152

${ }^{148}$ Id. at 1221 (citing Geier, 529 U.S. at 881).

149 Id.

${ }^{150} \mathrm{Id}$.

151 Id.

152 Wyeth, 129 S. Ct. at 1229 (Alito, J., dissenting). The brief of the United States stated, among other things:

[S]tate tort law that required a manufacturer to use different labeling than that approved by FDA would disrupt the agency's balancing of health risks and benefits. The FDA-approved labeling gives specific instructions on how to inject Phenergan intravenously; respondent, in contrast, would impose further limits on such injection-limits that might harm some patients' health by restricting their physicians' treatment options. If a state regulatory agency directed drug manufacturers not to use FDA-approved labeling, the conflict with federal law would be manifest. As in Riegel, the fact that juries instead of an expert agency would second-guess FDA's judgments in individual cases only exacerbates the conflict. 
Moreover, the dissent noted that the preemption doctrine had important policy implications. It observed that "drug labeling by jury verdict undermines both our broader pre-emption jurisprudence and the broader workability of the federal drug-labeling regime."153 The dissent reasoned that "[b]y their very nature, juries are ill-equipped to perform the FDA's costbenefit-balancing function" because they "tend to focus on the risk of a particular product's design or warning label that arguably contributed to a particular plaintiff's injury, not on the overall benefits of that design or label." 154 In contrast, the FDA may take a "long view" that considers the interests of "all potential users of a drug."155

The dissent believed that this was particularly true under the particular circumstances of this case:

To be sure, state tort suits can peacefully coexist with the FDA's labeling regime, and they have done so for decades. . . But this case is far from peaceful coexistence. The FDA told Wyeth that Phenergan's label renders its use "safe." But the State of Vermont, through its tort law, said: "Not so."156

Thus, both the majority and the dissent recognized that these were significant concerns underlying the preemption doctrine. Nonetheless, because of their different assessments of the record, they came to different conclusions regarding whether these concerns were implicated under the circumstances of the case. In addition, the dissent noted that plaintiff was not left without a remedy for her injury. Rather, it asserted that she may have "an ideal medical-malpractice case."157

\section{THE SCOPE OF PREEMPTION AFTER WYETH}

While some commentators have suggested that Wyeth deals a significant blow to those seeking to invoke the preemption doctrine to bar state lawsuits involving pharmaceutical products, the decision itself demonstrates that the

Brief for the United States, supra note 124, at 9.

153 Wyeth, 129 S. Ct. at 1222 (Alito, J., dissenting); see also id. at 1220 ("Neither the FDCA nor its implementing regulations suggest that juries may second-guess the FDA's labeling decisions.").

154 Id. at $1229-30$.

155 Id. at 1230 .

156 Id. at 1231.

${ }^{157}$ Id. at 1218 . The dissent noted that the plaintiff had, in fact, brought and settled such a suit against her physician, the physician's assistant, and the hospital at which she was treated. See id. at 1218 n.3. 
preemption doctrine is far from dead. Rather, the logic of the decision makes clear that the doctrine should apply where the record demonstrates that the FDA has actually considered the risks at issue in the state lawsuit and thus provided an analysis that might conflict with state-law tort liability.

\section{A. A Context-Dependent Analysis}

The Court specifically preserved preemption claims where the record indicates that the FDA has actually considered a particular risk, and yet has not required an additional warning. Its decision in this regard was consistent with other lower court decisions, which had focused on the FDA's actual consideration of the risks at issue in determining that state-law claims were preempted. ${ }^{158}$ Thus, the Court's decision in Wyeth is best viewed as a narrow one that was not intended to work a major shift in the Court's preemption jurisprudence.

This is further borne out by the Court's treatment of another recent pending case concerning preemption of state law claims involving a pharmaceutical product, Colacicco v. Apotex Inc. ${ }^{159}$ In Colacicco, the Third Circuit held that, where the FDA had specifically rejected the need for an additional warning regarding the risk of suicide in patients taking antidepressant SSRIs, plaintiff's claims challenging the absence of the additional warning were preempted. ${ }^{160}$ The Supreme Court did not

158 See, e.g., Dowhal v. Smithkline Beecham Consumer Healthcare, 88 P.3d 1 (Cal. 2004); In re Bextra \& Celebrex Mktg. Sales Practices \& Prod. Liab. Litig., No. 05-1699 CRB, 2006 WL 2374742, at *10 (N.D. Cal. Aug. 16, 2006) (cardiovascular risk claims preempted where FDA "specifically considered whether Celebrex poses a greater risk of adverse cardiovascular events than other NSAIDS" and found that the claim was "scientifically unsubstantiated"); Needleman v. Pfizer Inc., No. 3:03-CV-3074-N, 2004 WL 1773697 , at *2 (N.D. Tex. Aug. 6, 2004) (holding claims preempted where "FDA has clearly determined that a warning linking Zoloft and suicide would be false, misleading, and harmful to patients"); Dusek v. Pfizer Inc., No. H-02-3559, 2004 WL 2191804, at *9-10 (S.D. Tex. Feb. 20, 2004) (same).

159521 F.3d 253 (3d Cir. 2008), vacated, 129 S. Ct. 1578 (2009); see also Mary J. Davis, The Battle Over Implied Preemption: Products Liability and the FDA, 48 B.C. L. REV. 1089, 1098 (2007) (observing that "[a]n increasing number of prescription drug labeling cases have been defended successfully" on grounds similar to Colacicco).

160 Colacicco, 521 F.3d at 271, 276. Not only did the court conclude that the claims were preempted, but the United States filed an amicus brief in the case arguing for that result:

To base a tort judgment on drug manufacturers' failure to warn in October 2003 of an association between adult use of paroxetine hydrochloride and suicide or suicidality, despite FDA's judgment at that time that there was not reasonable scientific evidence of such an association, would be to demand a warning statement 
summarily reverse the Colacicco decision. Instead, it remanded the case "for further consideration" in light of its decision in Wyeth. ${ }^{161}$

The key factual distinction between Wyeth and Colacicco is spelled out in the Third Circuit's decision. Not only was the record clear in Colacicco that the FDA had considered the specific risks at issue in the litigation, but the court's rejection of the plaintiff's position regarding those risks was express:

In this case we need not speculate on the rationale of the FDA for its failure to require the adult suicidality warnings. Not only has the FDA filed an amicus brief in the Colacicco action but it has repeatedly rejected the scientific basis for the warnings that Colacicco and McNellis argue should have been included in the labeling. The FDA has actively monitored the possible association between SSRIs and suicide for nearly twenty years, and has concluded that the suicide warnings desired by plaintiffs are without scientific basis and would therefore be false and misleading. ${ }^{162}$

Among other things, the FDA had "specifically rejected citizen petitions in 1991, 1992, and 1997 which sought to either withdraw approval of Prozac as a result of its asserted association with suicide or to include a suicide warning on the labeling of that drug."163 After considering the matter, "[i]n each instance, the FDA concluded that there was insufficient evidence to take the actions requested."164 The FDA had also filed amicus briefs in pending litigation stating that it had concluded that there was "no scientific basis for a warning suggesting that Zoloft causes suicidality."165 While the FDA

that would have been false or misleading, and thus contrary to federal law. In such a case, as the district court properly recognized, federal law must prevail.

Brief of the United States as Amicus Curiae in Support of Defendants-Appellees at 2, Colacicco v. Apotex Inc., 521 F.3d 253 (3d Cir. 2008) (No. 06-3107).

161 Colacicco v. Apotex, Inc., 129 S. Ct. 1578, 1578-79 (2009).

162 Colacicco, 521 F.3d at 269 (citation omitted). As the court explained, this conflict was sufficient to preempt the state law claims:

Because the standard for adding a warning to drug labeling is the existence of "reasonable evidence of an association of a serious hazard with a drug," and the FDCA authorizes the FDA to prohibit false or misleading labeling, a state-law obligation to include a warning asserting the existence of an association between SSRIs and suicidality directly conflicts with the FDA's oft-repeated conclusion that the evidence did not support such an association.

Id. at 271 (footnote omitted).

163 Id. at 269.

164 Id.

165 Id. at 270. 
engaged in a reevaluation of the evidence linking suicide to SSRIs in pediatric and adult patients, at the same time "the FDA continued to announce its rejection of adult suicidality warnings for SSRIs." 166 As a result, the court observed, it need go no further:

[W]e need not decide whether preemption would be appropriate under different facts-such as where the FDA had not rejected the substance of the warning sought or where the FDA only stated its position after a lawsuit had been initiated - or under the broader theories of preemption argued by the parties. ${ }^{167}$

The FDA had "clearly and publicly stated its position." 168 Indeed, the court expressly contrasted the facts before it with those facing the Vermont Supreme Court in Wyeth, which had found that there was no record evidence that the FDA had considered the specific risks at issue. 169

Another example of this sort of conflict is presented in the California Supreme Court's decision in Dowhal v. Smithkline Beecham Consumer Healthcare. ${ }^{170}$ There, the court held that there was a conflict between warnings for over-the-counter smoking cessation products under California law and those required by the FDA. Specifically, the State of California had sought to require additional warnings regarding the use of nicotine replacement therapies by pregnant women. The FDA had expressly denied the manufacturers' request to conform their warnings to those required under California law, fearing that the additional warnings overstated the risks and might discourage the use of such products by women who smoked, and had indicated that "[a]ny additional or modified warning may render the product

166 Colacicco, 521 F.3d at 271.

$167 \mathrm{Id}$.

168 Id.

${ }^{169} \mathrm{Id}$. at 272 n.17. Likewise, in opposing Wyeth's petition for certiorari, plaintiff had argued that the case "does not genuinely present [the] question" whether "“labeling judgments' made by the FDA regarding a drug's safety and efficacy preempt state-law product liability claims premised on 'differing label judgments"' because "the Vermont Supreme Court correctly found, as a matter of fact, that Ms. Levine's recovery was not based on a labeling judgment different from a labeling judgment made by the FDA." Respondent's Supplemental Brief in Response to Brief of the United States at 5, Wyeth v. Levine, 129 S. Ct. 1187 (2009) (No. 06-1249). As plaintiff explained, "Wyeth's claim for preemption rests on its assertion that the FDA had specifically considered and rejected a label change that would have prohibited IV-push administration of Phenergan. But the Vermont Supreme Court rejected that argument as having no factual basis in the record." Id.

17088 P.3d 1 (Cal. 2004). 
misbranded."171 While the FDA allowed the manufacturers to modify the warnings in some respects, it denied the request to conform the warnings to the specific language required under California law. ${ }^{172}$

Given this conflict between state and federal regulation, the California Supreme Court held that the preemption doctrine applied. ${ }^{173}$ As the court observed, the FDA-approved warning label implemented "a nuanced goalto inform women of the risks of [nicotine replacement therapy] products, but in a way that will not lead some women, overly concerned about those risks, to continue smoking."174 The State of California, in contrast, sought to implement a "more single-minded goal of informing the consumer of the risks," even if such additional warnings might discourage the beneficial use of nicotine replacement products. ${ }^{175}$

\section{B. Preemption After Notice-and-Comment Rulemaking}

As Justice Breyer's concurrence suggests, an even broader principle of preemption may apply where it is specifically endorsed by the FDA after notice-and-comment rulemaking. In Geier, ${ }^{176}$ for example, the Department of Transportation had engaged in such formal rulemaking. ${ }^{177}$ The Court held that, under such circumstances, claims inconsistent with the Department of Transportation's approach were preempted. The majority in Wyeth did not purport to overrule Geier in this respect. Indeed, the majority specifically relied upon that decision in distinguishing the lack of formal rulemaking in the case of the FDA's labeling preamble, which did not allow states to have any input in the FDA's decisionmaking. ${ }^{178}$

As Justice Breyer observed, this is significant given that it preserves the FDA's ability to preempt state action that might interfere with its expert assessment of the safety and efficacy of pharmaceutical products. As a result, if the FDA believes that the states are encroaching on its ability to carry out its mission, it can act affirmatively to preempt their ability to do so. Thus, under the Court's broad view of the preemption doctrine, not only the elected

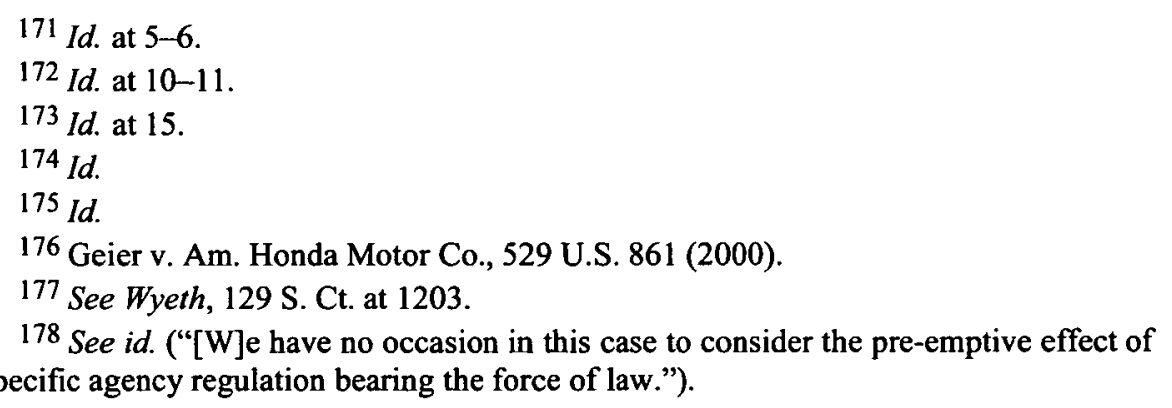


officials in Congress, but federal agencies such as the FDA may directly impact the scope of state activity.

\section{Preemption Where There Is an Approved Use}

There may be other situations in which there is such an apparent conflict between FDA regulation and a state tort suit requiring the application of the preemption doctrine. As the majority observed, it was not called upon to decide "whether a state rule proscribing intravenous administration [of Phenergan] would be pre-empted." 179 There may be particular problems with bringing claims alleging that pharmaceutical products are unsafe where the FDA has specifically approved the product as safe and effective.

Both the majority and the Vermont Supreme Court held that there was no need to address this question because the continued use of the IV-push means of administration was not at issue in the state lawsuit. Nonetheless, the dissent issued by the Chief Justice of the Vermont Supreme Court lays out the framework for the argument in favor of preemption under such circumstances. ${ }^{180}$ It is difficult to reconcile a state law claim that effectively asks a jury to conclude that a particular product should not be on the market or a means of use should be prohibited where the FDA has specifically addressed the issue and has concluded that the benefits outweigh the risks. Such decisions would significantly undermine the FDA's regulatory authority. Moreover, they would plainly present a direct conflict with FDA action. Under such circumstances, therefore, preemption is fully warranted.

\section{Preemption of Fraud-on-the-FDA Claims}

The ruling in Wyeth likewise does not purport to overrule the Court's prior ruling in Buckman that so-called fraud-on-the-FDA claims were preempted. ${ }^{181}$ To the contrary, the majority specifically noted that decision in its opinion. ${ }^{182}$ In Buckman, the Court found that "[s]tate-law fraud-on-theFDA claims inevitably conflict with the FDA's responsibility to police fraud

${ }^{179}$ Id. at 1194.

${ }^{180}$ See supra Section I.E.2.

181531 U.S. 341,353 (2001). For a discussion of Buckman, see Ausness, supra note 92 , at $960-62$.

182 Wyeth, 129 S. Ct. at 1195 n.3. 
consistently with the Administration's judgment and objectives."183 Accordingly, such claims were squarely preempted.

This aspect of the preemption doctrine works in conjunction with preemption of failure-to-warn claims. Where plaintiffs cannot allege a failure to warn because such claims would be preempted, they may argue that the FDA did not have all of the information necessary to evaluate the safety of a pharmaceutical product or the appropriateness of its labeling because the manufacturer allegedly withheld adverse information from the FDA. Buckman makes clear that such claims are likewise preempted because Congress understood that the FDA would have authority to police such activity. ${ }^{184}$ The two doctrines therefore complement each other by prohibiting plaintiffs from circumventing the preemption doctrine that would otherwise bar their failure-to-warn claims.

\section{WYETH IN THE CONTEXT OF THE COURT'S OTHER PREEMPTION CASES}

Despite the narrow holding in Wyeth, the Court's preemption decisions overall manifest a strong defense of the doctrine in cases in which federal regulation may conflict with state lawsuits. ${ }^{185}$ As noted above, the Court in Wyeth did not purport to overrule these prior precedents. For example, it specifically distinguished Geier on its facts, arguing that the case was distinguishable because in Geier there was an actual conflict between Department of Transportation regulation of air bags and the state action being challenged. Likewise, the Court did not purport to overrule precedents such as Buckman, which held that fraud-on-the-FDA claims were

183531 U.S. at 350.

184 See, e.g., Colacicco v. Apotex Inc., 521 F.3d 253, 271 (3d Cir. 2008) (noting that not only failure-to-warn claims, but also plaintiff's fraud-on-the-FDA claims were preempted), vacated, 129 S. Ct. 1578 (2009); In re Bextra \& Celebrex Mktg. Sales Practices \& Prod. Liab. Litig., No. 05-1699 CRB, 2006 WL 2374742, at *10 (N.D. Cal. Aug. 16, 2006) ("The law is well established that a claim premised on a drug manufacturer's failure to provide data to the FDA is preempted.").

185 For a general discussion of the preemption doctrine, see Viet D. Dinh, Reassessing the Law of Preemption, 88 GEO. L.J. 2085 (2000); Stephen A. Gardbaum, The Nature of Preemption, 79 CORNELL L. REV. 767 (1994); Roderick M. Hills, Jr., Against Preemption: How Federalism Can Improve the National Legislative Process, 82 N.Y.U. L. REV. 1 (2007); Caleb Nelson, Preemption, 86 VA. L. ReV. 225, 252 (2000). 
preempted, 186 or Riegel, which held that the preemption doctrine barred certain claims regarding medical devices. ${ }^{187}$

These precedents, taken together, evidence a broad trend in favor of an expansive preemption doctrine. Indeed, as Justice Thomas noted in his concurrence, it is a doctrine that in many respects has been construed extremely broadly, extending to situations in which it is not completely clear that state action would impede federal goals or objectives and relying on a wide range of indirect evidence to demonstrate that there is some inconsistency between federal and state action. ${ }^{188}$

This trend seems motivated, in part, by a skepticism regarding jury decision making, particularly when contrasted with the expert decision making involved in FDA regulation. In Riegel, for example, the majority observed that "[s]tate tort law that requires a manufacturer's catheters to be safer, but hence less effective, than the model the FDA has approved disrupts the federal scheme no less than state regulatory law to the same effect." 189 In fact, the Court opined that "tort law, applied by juries under a negligence or strict-liability standard, is less deserving of preservation" because "[a] state statute, or a regulation adopted by a state agency, could at least be expected to apply cost-benefit analysis similar to that applied by the experts at the FDA." 190 In contrast, a jury deciding a negligence action "sees only the cost of a more dangerous design, and is not concerned with its benefits; the patients who reaped those benefits are not represented in court."191

The Court in Buckman likewise cited the importance of the FDA's expert review and the "delicate balance of statutory objectives" inherent in that analysis. ${ }^{192}$ The Court noted that the FDA's review involves "difficult (and often competing) objectives." 193 Among other things, the FDA must ensure that drugs are both safe and effective while at the same time allowing beneficial drugs to proceed promptly to market. ${ }^{194}$ In addition, it must regulate in a manner that does not "intrud[e] upon decisions statutorily committed to the discretion of health care professionals."195

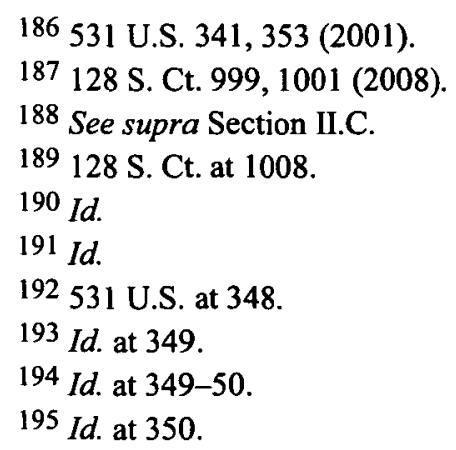


Even those cases in which the Court has found that there is no preemption give important guidance. For example, in Bates v. Dow Agrosciences $L L C$, the Court held that the Federal Insecticide, Fungicide, and Rodenticide Act (FIFRA) did not preempt claims for defective design, defective manufacture, negligent testing, breach of express warranty, or violation of the Texas Deceptive Trade Practices Act in a case brought by Texas peanut farmers who were complaining that their crops were damaged by herbicide sold by Dow Agrosciences. ${ }^{196}$ However, the Court remanded for further proceedings as to the plaintiffs' fraud and failure-to-warn claims, emphasizing that "a state-law labeling requirement must in fact be equivalent to a requirement under FIFRA in order to survive pre-emption." 197 In particular, the Court noted that "a failure-to-warn claim alleging that a given pesticide's label should have stated 'DANGER' instead of the more subdued 'CAUTION' would be pre-empted because it is inconsistent with 40 CFR $\S 156.64$ (2004), which specifically assigns these warnings to particular classes of pesticides based on their toxicity." 198

A similar rule may be applied in the context of pharmaceutical products. Where the FDA has specifically considered the particular risks at issue in a state lawsuit and has crafted particular warnings to address those risks, state lawsuits claiming that such warnings are inadequate may be preempted. The common theme running through cases such as Wyeth and Bates is that, where a federal agency specifically considers an issue, inconsistent state-law action should be barred.

\section{The BALANCE THE COURT HAS STRUCK}

While the Wyeth decision does not authorize across-the-board, automatic preemption for all failure-to-warn claims, it does provide guidance to determine which claims may be preempted. In doing so, the Court has struck a balance between several important considerations. One may ask whether an across-the-board rule of preemption would be preferable given the significant costs associated with modern-day tort litigation. Nonetheless, the Court's

196544 U.S. 431, 452 (2005).

197 Id. at 453.

${ }^{198}$ Id. Justice Thomas and Justice Scalia elaborated on these requirements in their separate concurrence, noting that "[a] state-law cause of action, even if not specific to labeling, nevertheless imposes a labeling requirement 'in addition to or different from' FIFRA's when it attaches liability to statements on the label that do not produce liability under FIFRA." Id. at 456 (Thomas, J., concurring in the judgment in part and dissenting in part). 
decision arguably preserves many of the benefits of the preemption doctrine while avoiding certain potential costs.

First, Wyeth preserves the preemption doctrine in cases where there is an actual conflict between FDA regulation and state litigation. In doing so, it avoids certain potentially unnecessary costs of the preemption doctrine by making clear that if the FDA has not considered a particular risk in crafting labeling for a pharmaceutical product, then state law failure-to-warn claims are not preempted. This avoids a situation where preemption may be applied to bar a state-law claim where there is no actual conflict between federal and state regulation. In such circumstances, the rationale for the preemption doctrine is absent. However, at the same time, the Court's decision preserves the benefits of the preemption doctrine by making clear that it applies in cases where the FDA has actually considered the particular risks at issue and as a result there is an actual conflict.

Second, the Court has retained the preemption doctrine in cases where there is a genuine concern that jury decision making might undermine the expert balancing of risks and benefits by the FDA. 199 Because the preemption doctrine applies in cases where the FDA has considered particular risks and engaged in a balancing of those risks against the benefits of a pharmaceutical product, it ensures that juries will not be allowed to second-guess such expert decision making. Where, in contrast, no such process has been undertaken, the Court's decision in Wyeth holds that the preemption doctrine is inapplicable. Again, the Court has drawn a line that arguably preserves the benefits of the preemption doctrine while avoiding unnecessary costs.

Third, the Court's decision will prevent the imposition of unwarranted liability in appropriate circumstances. These costs can be significant, preventing innovation and the development of pharmaceutical products that

199 Cf. Medtronic, Inc. v. Lohr, 518 U.S. 470, 496 (1996) (FDA “is uniquely qualified to determine whether a particular form of state law stands as an obstacle to accomplishment and execution of the full purposes and objectives of Congress"); Weinberger v. Bentex Pharms. Inc., 412 U.S. 645, 654 (1973) (observing that "[t]he determination whether a drug is generally recognized as safe and effective ... necessarily implicates complex chemical and pharmacological considerations ... within the [FDA's] peculiar expertise"); Peter Huber, Safety and the Second Best: The Hazards of Public Risk Management in the Courts, 85 CoLUM. L. REV. 277, 335 (1985) (observing that, while "[r]egulatory agencies are equipped to make the risk comparisons on which all progressive transformation of the risk environment must be based," "[ $t]$ he courts are simply not qualified to second-guess such decisions" and that when they do so, "they routinely make regressive risk choices"). 
may have significant benefits. ${ }^{200}$ Where the FDA has considered particular risks and addressed them as it deemed appropriate in its expert opinion, juries will be prevented from imposing liability. The Court's decision in this regard therefore preserves an important benefit of the preemption doctrine. Nonetheless, the Court could have gone even further. There may be instances in which the FDA has not considered a particular risk, either because it emerged after FDA approval or because it was not brought to the FDA's attention. The preemption doctrine may not apply in such circumstances even though the particular risk does not warrant the imposition of liability. Thus, the Wyeth decision may forego certain potential benefits of a broader preemption doctrine. Nonetheless, it avoids the costs associated with a situation where a risk was not considered by the FDA and actually does warrant the imposition of liability. ${ }^{201}$ In such circumstances, an across-theboard rule of preemption would bar liability where, on balance, it may potentially be appropriate. The Court's line drawing avoids these costs, but only at a price - by giving up certain additional benefits that might be obtained under a broader preemption doctrine.

Fourth, the Court's decision will prevent "overwarning" that might result in the inappropriate use of a pharmaceutical product due to confusion or which might actually discourage the use of beneficial drugs. ${ }^{202}$ As the FDA

200 See, e.g., Louis Lasagna, The Chilling Effect of Product Liability on New Drug Development, in THE LIABILITY MAZE: THE IMPACT OF LIABILITY LAW ON SAFETY AND INNOVATION 334, 335-37 (Peter W. Huber \& Robert E. Litan eds., 1991); Lars Noah, Triage in the Nation's Medicine Cabinet: The Puzzling Scarcity of Vaccines and Other Drugs, 54 S.C. L. REv. 371,392 (2002); W. Kip Viscusi et al., A Statistical Profile of Pharmaceutical Industry Liability, 1976-1989, 24 SETON HALL L. REV. 1418, 1419 (1994) (noting that "the net effect of the surge in liability costs had been to discourage innovation in the pharmaceutical industry"); see also Howard A. Denemark, Improving Litigation Against Drug Manufacturers for Failure to Warn Against Possible Side Effects: Keeping Dubious Lawsuits from Driving Good Drugs off the Market, 40 CASE W. RES. L. REV. 413, 413 (1989-1990) ("Beneficial drugs, approved by [the FDA], have been forced off the market by the current legal standards for imposing a duty on drug manufacturers to warn of adverse side effects from their drugs."); Margaret Gilhooley, Innovative Drugs, Products Liability, Regulatory Compliance, and Patient Choice, 24 SETON HALL L. REV. 1481, 1483 (1994) ("[M]edical experts have expressed concern that uncertain liability standards, coupled with litigation costs, may discourage useful drug innovation.").

${ }^{201}$ See Denemark, supra note 200, at 431 (arguing that "the FDA can rely on the incentives of the tort system to encourage manufacturers to continue research, reveal research results honestly, monitor scientific literature, and request or issue appropriate warnings" and that "[p]reemption would remove those incentives").

202 See Requirements on Content and Format of Labeling for Human Prescription Drug and Biological Products, 71 Fed. Reg. 3922, 3935 (Jan. 24, 2006) ("Overwarning, 
observed in its 2006 regulations, adding too much information to the labeling "could result in scientifically unsubstantiated warnings and underutilization of beneficial treatments." 203 "[L]abeling that includes theoretical hazards not well-grounded in scientific evidence can cause meaningful risk information to 'lose its significance."'204 In addition, overcrowding of labels with unnecessary warnings may "limit physician appreciation of potentially far more significant contraindications and side effects." 205 Because the preemption doctrine applies in cases where the FDA has specifically considered potential risks, overwarning may be avoided at least where the FDA has actually acted. Again, the Court's decision does not extend the preemption doctrine to every instance in which there may be a tangible benefit. Where the FDA has not considered the issue, the doctrine may not always apply. However, the Court's decision nonetheless does preserve these benefits in a large category of cases.

Fifth, the Wyeth decision may result in the creation of some new and additional costs and, potentially, some additional benefits. Because preemption applies in circumstances where the FDA has actually considered certain risks, manufacturers will have an incentive to submit as much

just like underwarning, can ... have a negative effect on patient safety and public health."); W. Kip Viscusi, Individual Rationality, Hazard Warnings, and the Foundations of Tort Law, 48 RUTGERS L. REV. 625, 665-66 (1996) ("Excessive warnings are not innocuous.... [ $] \mathrm{f}$ warnings are included for inconsequential risks, they will serve to further dilute the warnings for the real hazards that should be identified to consumers."). But see Mary J. Davis, The Battle Over Implied Preemption: Products Liability and the FDA, 48 B.C. L. REV. 1089, 1140-41 (2007) (questioning concerns regarding overwarning).

20371 Fed. Reg. at 3935 . Even before the 2006 regulations, the FDA observed that "it would be inappropriate to require statements in drug labeling that do not contribute to the safe and effective use of the drug, but instead are intended solely to influence civil litigation in which the agency has no part." Content and Format for Labeling for Human Prescription Drugs, 44 Fed. Reg. 37,434, 37,435 (June 26, 1979).

204 Requirements on Content and Format of Labeling, 71 Fed. Reg. at 3935.

205 Id. As the FDA explained:

Given the comprehensiveness of FDA regulation of drug safety, effectiveness, and labeling under the act, additional requirements for the disclosure of risk information are not necessarily more protective of patients. Instead, they can erode and disrupt the careful and truthful representation of benefits and risks that prescribers need to make appropriate judgments about drug use. Exaggeration of risk could discourage appropriate use of a beneficial drug.

Id. The FDA further noted that this problem was of particular concern because "[i]n recent years, there has been an increase in the length, detail, and complexity of prescription drug labeling, making it harder for health care practitioners to find specific information and to discern the most critical information." Id. at 3922. 
information as possible to the FDA both at the initial approval stage and in subsequent submissions. This may result in the FDA being deluged with information that may have only marginal value. ${ }^{206}$ On the other hand, it does give manufacturers an added incentive to make full and complete disclosure to the FDA. Accordingly, the Court's decision in Wyeth may create some additional costs, and potentially benefits, in terms of the regulatory process.

Sixth, the decision in Wyeth gives manufacturers an incentive to implement CBE amendments to their labeling more readily in order to avoid gaps in the preemption doctrine. This may again lead to potential costs as manufacturers implement changes to their labeling of dubious value simply to avoid the risk of potential liability for failure to act. Likewise, it may increase the FDA's workload given that, ultimately, the agency must review all such labeling changes. ${ }^{207}$ Finally, it may impose an unnecessary risk on manufacturers that their label change will be rejected and their amended label will be deemed misleading. ${ }^{208}$ The Food and Drug Act specifically prohibits the introduction into commerce of misbranded drugs, which includes drugs whose labeling is "false or misleading in any particular" or lacks "adequate directions for use."209

Finally, the Wyeth decision does provide some level of protection for the traditional role of the states in this area and thus furthers to some extent the principles of federalism. ${ }^{210}$ The Court could have gone much farther in this regard, holding, for example, that state law failure-to-warn claims are never preempted. Nonetheless, by holding that such claims were not always

206 The Supreme Court noted a similar concern in Buckman Co. v. Plaintiffs' Legal Committee, observing that allowing state-law fraud-on-the-FDA claims might cause manufacturers "to submit a deluge of information that [FDA] neither wants nor needs." See 531 U.S. 341, 351 (2001).

207 See Supplements and Other Changes to an Approved Application, 21 C.F.R. $\S 314.70(c)(6)(2009)$.

208 As the FDA explained in its 2006 preamble:

While a sponsor is permitted to add risk information to the [label] without first obtaining FDA approval via a CBE supplement, FDA reviews all such submissions and may later deny approval of the supplement, and the labeling remains subject to enforcement action if the added information makes the labeling false or misleading under section 502(a) of the act....

Requirements on Content and Format, 71 Fed. Reg. at 3934. Some of this risk may be mitigated, however, by consulting with the FDA prior to adding any information to the labeling.

${ }^{209}$ Federal Food, Drug, and Cosmetic Act, 21 U.S.C. \$§ 331(a), 352(a), (f) (2006).

210 See Medtronic, Inc. v. Lohr, 518 U.S. 470, 485 (1996) ("[B]ecause the States are independent sovereigns in our federal system, we have long presumed that Congress does not cavalierly pre-empt state-law causes of action."). 
preempted and requiring that there be an actual conflict between state litigation and federal regulation before the preemption doctrine applied, the Court preserved to some extent the role of the states in this area.

\section{CONCLUSION}

At bottom, the outcome in Wyeth $v$. Levine was strongly dependent on the unique factual record in that case. The majority construed the record as lacking evidence showing that the FDA had actually considered the risks at issue in the state-law tort suit. Without such consideration, there could be no conflict and thus no preemption, at least under the unique circumstances presented in Wyeth. Indeed, much of the dissent focused on attempting to dispute the majority's characterization of the record with respect to this critical finding.

As a result, the decision cannot be viewed as a sweeping prohibition on the use of preemption in the context of FDA-approved pharmaceutical products. Kather, the majority's opinion leaves room for application of the doctrine in circumstances where the record demonstrates that the FDA or other federal agencies have specifically considered the risks at issue in the state court lawsuit. Where such consideration exists, there exists the potential for a conflict between the FDA's reasoned judgment and the outcome of a state-law tort suit alleging a failure to warn.

A contrary ruling would be inconsistent with the Court's other preemption decisions, such as its decision in Geier. ${ }^{211}$ The Court there noted the important policies underlying the preemption doctrine and gave it broad effect to ensure that federal objectives were not undermined by state court actions and to preserve uniformity where the federal government had decided to act.

It would also lead to undesirable consequences as a practical matter. In addition to the potential problems associated with a lack of uniformity that would develop if juries in fifty-two separate jurisdictions could independently craft standards that were inconsistent with federal standards, such an outcome would undermine the value of having such determinations made by experts at the federal level in a process in which all affected parties

211 See, e.g., CSX Transp., Inc. v. Easterwood, 507 U.S. 658, 674-75 (1993) (federal maximum train speed regulation preempted negligence suit alleging excessive train speed); City of New York v. FCC, 486 U.S. 57, 66-67 (1988) (FCC regulation establishing standards for cable television signal quality preempted inconsistent state regulation); Fid. Fed. Sav. \& Loan Ass'n v. de la Cuesta, 458 U.S. 141, 170 (1982) (Federal Home Loan Bank Board regulation regarding due-on-sale clauses in mortgages preempted contrary state common law rule). 
may participate. Federal agencies such as the FDA have been created, at least in part, precisely because there is a value to having a single entity with nationwide authority making decisions that necessarily require the application of specialized expertise to sometimes highly technical scientific information. Such decisions could well have been left to individual states. However, Congress chose to establish a federal regulatory regime precisely to avoid the potential pitfalls associated with state-by-state regulation in this important area. Thus, some form of the preemption doctrine is arguably needed to give effect to these federal policies.

Once one has decided to establish a federal regulatory system, it makes little sense to allow state regulation, much less the decisions of individuals randomly selected from the general population who lack the specialized expertise of federal regulators, to undermine that very system. Accordingly, both the Court's precedents, and common sense warrant the continued application of the preemption doctrine. 